\title{
MARINE LIFE OF URUGUAY: CRITICAL UPDATE AND PRIORITIES FOR FUTURE RESEARCH
}

\author{
LA VIDA MARINA DE URUGUAY: REVISION CRITICA Y PRIORIDADES \\ PARA INVESTIGACIONES FUTURAS
}

\section{Danilo Calliari ${ }^{1}$, Omar Defeo², Guillermo Cervetto ${ }^{1}$, Mónica Gómez ${ }^{1}$, Luis Giménez ${ }^{1}$, Fabrizio Scarabino ${ }^{2,3}$, Alejandro Brazeiro ${ }^{4} \&$ Walter Norbis ${ }^{1}$}

${ }^{1}$ Sección Oceanología, Facultad de Ciencias, Universidad de la República, Iguá 4225 CP 11400, Montevideo, Uruguay.

${ }^{2}$ Unidad de Ciencias del Mar, Facultad de Ciencias, Universidad de la República, Iguá 4225 CP 11400, Montevideo, Uruguay.

${ }^{3}$ Dirección Nacional de Recursos Acuáticos (DINARA). Constituyente 1497, Montevideo, Uruguay

${ }^{4}$ Sección Ecología, Facultad de Ciencias, Universidad de la República, Iguá 4225 CP 11400, Montevideo, Uruguay

\begin{abstract}
The marine areas of Uruguay consist of the Río de la Plata estuary and the adjacent shelf and slope, part of the Subtropical Convergence Ecosystem. In this paper, the main advances in the knowledge of marine life in these areas (the known) are reviewed in order to discuss future lines of research (the unknown). Information has been separately analysed for the plankton, nekton, and benthos in each of 3 areas-the littoral, the shelfs and the "open ocean". Current knowledge of marine life is uneven among the groups and areas. In the case of the plankton, research has concentrated on the near-shore waters and focused on taxonomy and distribution. Little is known about the responses of organisms to environmental variability and about biological processes. The nekton of coastal and estuarine areas is better known, but, with shelf and slope assemblages, research has focused on exploited species. The main unknowns for the nekton are how trophodynamics, reproduction, and recruitment processes are linked to environmental variability and the effect of fisheries on community structure. Littoral benthos, in particular the macroinfauna of sandy beaches, is much better studied and spatial patterns of community distribution have been identified at different scales and in relation to environmental variables. Also, at the population level, there is information about distribution, responses to disturbances, dynamics, and the roles of biotic and abiotic factors in modulating population variability. Information is mainly lacking for the sub-tidal fringe and regarding the macro-ecology of population dynamics, the dispersive abilities of larval phases, and the effects of toxic blooms on suspension feeders. Knowledge of the benthos of estuaries and more so of the shelf and slope environments is rather scarce. For the latter two, faunal inventories are far from complete. Topics identified for future research include taxonomy, macro-scale community structure and its temporal variability in relation to environmental gradients, diverse aspects of population dynamics trophodynamics and the effects of human intervention on ecosystems. The incorporation of both experimental and modelling approaches is considered important for future investigations.
\end{abstract}

KeYwords: Marine life; Biodiversity; Río de la Plata; Atlantic Ocean, Uruguay.

\section{RESUMEN}

Las aguas uruguayas comprenden el estuario del Río de la Plata y la plataforma y talud contiguos, parte del Ecosistema de Convergencia Subtropical. Esta contribución revisa los principales avances en el conocimiento de la vida marina en esta zona (lo conocido), para discutir futuras líneas de investigación (lo desconocido). Se analiza separadamente la información del plancton, necton y bentos de tres áreas: litoral, plataforma y "océano profundo". El conocimiento resulta disparejo entre grupos y entre áreas. En el plancton, la investigación se concentró en el litoral y enfocada hacia 
aspectos taxonómicos y de distribución, existiendo fuertes deficiencias en el conocimiento de las respuestas de los organismos a la variabilidad ambiental y de procesos biológicos. El necton de áreas estuarinas y costeras es mejor conocido que el de plataforma y talud, donde la investigación ha sido dirigida principalmente a especies explotadas. En este grupo, los principales aspectos desconocidos son los trofodinámicos, los procesos reproductivos y de reclutamiento en función de la variabilidad ambiental, y el efecto de las pesquerías sobre la estructura comunitaria. El bentos litoral, en particular la macroinfauna de playas arenosas, es el componente mejor conocido: se han establecido patrones de distribución comunitaria en diferentes escalas espaciales y en relación a variables ambientales. A nivel poblacional existe información sobre distribución, repuesta a perturbaciones, dinámica, y sobre el papel de factores bióticos y abióticos en la modulación de la variabilidad poblacional. La información faltante se refiere a la franja submareal, así como a aspectos macro ecológicos de dinámica poblacional, dispersión larval y el efecto de las floraciones tóxicas sobre organismos suspensívoros. El bentos de estuarios, y en particular aquél de plataforma y talud, es muy poco conocido; para los últimos los inventarios faunísticos son extremadamente incompletos. Los tópicos identificados para próximas investigaciones incluyen taxonomía, la estructura de las comunidades y su variabilidad temporal en gradientes ambientales, diversos aspectos de dinámica poblacional, trofodinámica y el efecto de la intervención humana en los ecosistemas. Se considera muy importante la incorporación de enfoques experimentales y modelización.

Palabras claves: Vida Marina; Biodiversidad; Río de la Plata, Océano Atlántico; Uruguay.

\section{INTRODUCTION}

The marine domain of Uruguay is made up of the Río de la Plata and the adjacent shelf (Fig. 1) and shares ecosystems with Brazil and Argentina. Present understanding of the distribution of marine life and related ecological processes in the region is owed to contributions from local, regional, and international scientific communities. Knowledge is still rather limited, however, partially because some ecosystems have not been adequately investigated. Reviews (Méndez et al. 1997, Seeliger et al. 1997, Mianzán et al. 2000) about these and adjacent ecosystems have proved to be particularly useful because a large amount of the information produced so far is highly dispersed and not readily available as it is published in Journals of limited circulation or as technical reports. This paper updates the main advances regarding marine biota in order to identify future lines of research for Uruguay. It first summarizes the most conspicuous physical characteristics of the area, then, for each group (plankton, nekton, and benthos) and critically reviews what has been done to provide our current understanding of the distribution and dynamics of marine life (the known), with emphasis on the contributions from Uruguayan scientists. Finally, it discusses research priorities (the unknown) in the light of what is known.

The waters off Uruguay can be divided into two broad systems, the Río de la Plata (RdlP) and its zone of influence over the inner continental shelf, and the shelf/shelf-break ecosystem. They include a large coastal, estuarine influenced area, a wide continental shelf, and a slope and deep basin where the confluence of the Brazil Current (BC) and Falkland (Malvinas) Current (FC) takes place (Atlantic Subtropical Convergence).

The RdlP is a funnel-shaped, coastal plain, microtidal estuary situated at $34^{\circ} 10^{\prime}-36^{\circ} 10^{\prime} \mathrm{S}$, $55^{\circ} 00^{\prime}-58^{\circ} 10^{\prime} \mathrm{W}$. It is $200 \mathrm{~km}$ long and $230 \mathrm{~km}$ wide at the mouth between Punta del Este (Uruguay) and Cabo San Antonio (Argentina), with a surface area of ca. $38,000 \mathrm{~km}^{2}$. The main tributaries are the Paraná-Paraguay and Uruguay rivers, which drain the second largest basin in South America (Framiñan \& Brown 1996, Nagy et al. 1997) and provide the major source of freshwater runoff in the southwest Atlantic.

The upper estuary has very low salinities $(<1 \%$ ) and extremely turbid waters, whereas the lower estuary is somewhat less turbid with highly variable salinity in space and time (1-33\%o) strongly influenced by Atlantic Coastal Waters (a combination of BC, FC, and freshwaters from continental runoff (Guerrero et al. 1997). Upper and lower regions are separated by a salinity front -the upper reach of the salt wedge- and a turbidity front that almost overlap and present complex and variable geometries (Framiñan \& Brown 1996, Guerrero et al. 1997). Marine waters penetrate in the form of a salt wedge, and the characteristics of the 
gradients are dependent upon wind intensity and direction, freshwater runoff, and bottom topography (Guerrero et al. 1997, Nagy et al. 1997). The depth is less than $10 \mathrm{~m}$ over $>50 \%$ of its surface area with a maximum of $c a .25 \mathrm{~m}$ at the mouth.

In the upper estuary, bottom topography is characterised by a system of channels and banks, and sediments are composed of fine fractions, mainly silts and clays (López 1997). The Barra del Indio bank separates the upper estuary, dominated by extensive shallows (1-4 m deep, i.e. Playa Honda, Banco Ortiz) and coastal channels (5-8 m deep, Canal Oriental Oeste, Canal Intermedio), from the lower estuary. The latter is wider and deeper, which allows the development of a vertical structure in the water column (Framiñan \& Brown 1996), and the sediments are predominantly relict sands (López 1997).

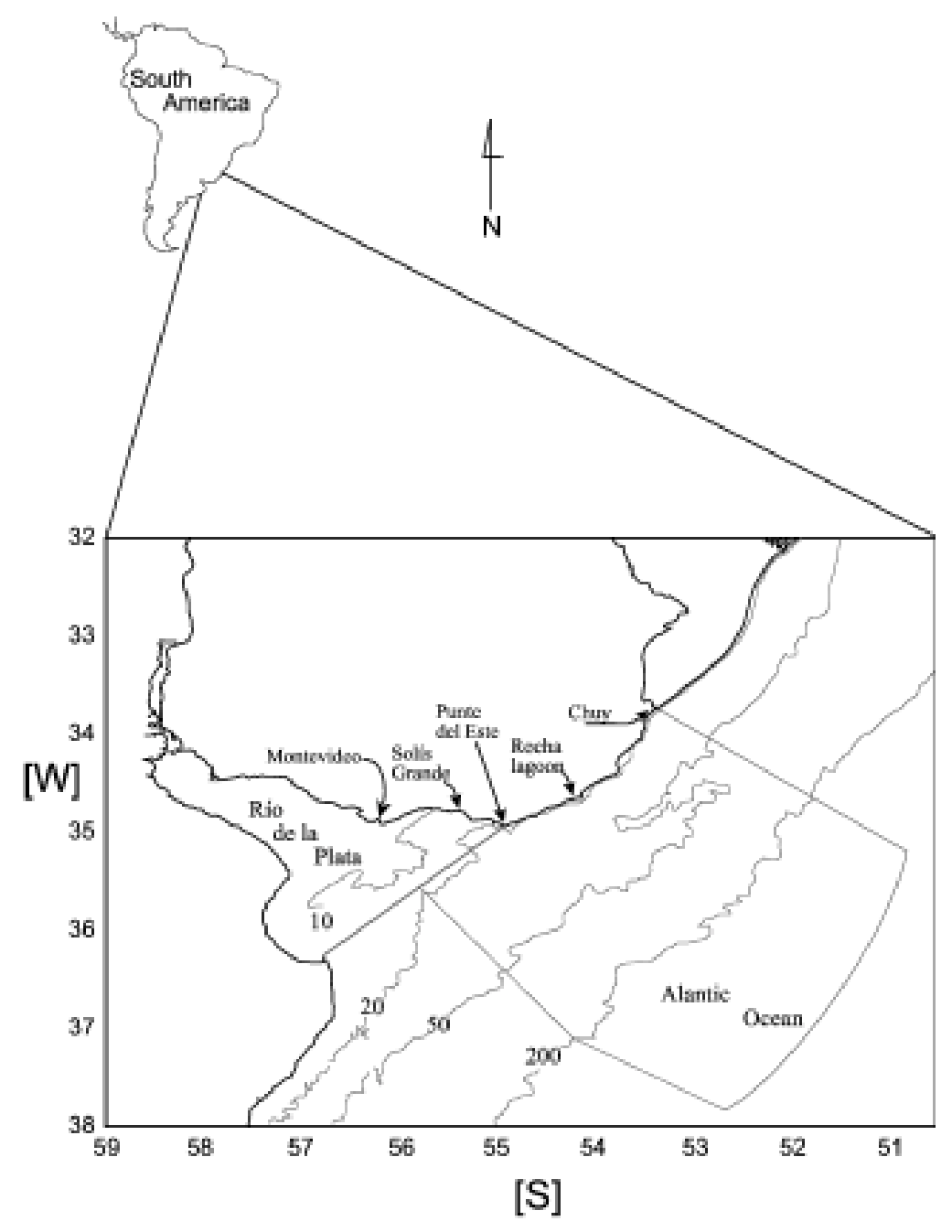

FIGURE 1. Map of Uruguayan waters, including the Río de la Plata waters shared with Argentina. Also indicated are major geographic references mentioned in the text.

Figura 1. Mapa de las aguas Uruguayas, incluyendo aquellas del Río de la Plata compartidas con Argentina. Se indican también las principales referencias geográficas mencionadas en el texto. 
The offshore environment is dominated by 2 major boundary currents, the poleward flowing $\mathrm{BC}$ and the equatorward FC. They appear as tongue-like structures that 'collide' off the RdlP, the former being deflected offshore while the latter slides inshore (Olson et al. 1988, Bakun \& Parrish 1991). Over the shelf, there is an onshore-offshore transition from continental influenced waters (Coastal Waters, CW) to Central Atlantic Waters (CAW). The inner shelf is occupied by $\mathrm{CW}$, a mixture of CAW and freshwater outflow from the RdlP and Patos Lagoon (Ciotti et al. 1995, García 1997). The plume of the RdlP moves NNE as a shallow surface layer along the Uruguayan coast in the austral autumn/ winter but southwards along the Argentinian coast in the spring/summer, the direction being determined by the balance between on- and offshore winds (Guerrero et al. 1997). The plume of RdlP brackish water over the shelf induces a fairly stable density profile (Castello \& Müller 1977, Bakun \& Parrish 1991).

Further offshore, surface CAW results from the mixing of $\mathrm{FC}$ and $\mathrm{BC}$ waters between $25^{\circ} \mathrm{S}$ and $45^{\circ}$ S (Olson et al. 1988, Garzoli \& Garrafo 1989, Gordon 1989, Bianchi et al. 1993, Odebrecht \& Castello 2000). BC water is warm, saline, and relatively oligotrophic (Bisbal 1995). It is a branch of the South Equatorial Current and flows poleward nearly parallel to the shelf-break. The cool, nutrient-rich FC branches off the Antarctic Circumpolar Current (ACC) flowing northward along the continental slope. The confluence of the $\mathrm{BC}$ and $\mathrm{FC}$ results in complex meso-scale circulation patterns like warm or cold-core rings, eddies, and filaments (Legeckis \& Gordon 1982, Olson et al. 1988, Gayoso \& Podestá 1996). The zone between $30^{\circ} \mathrm{S}$ and $40^{\circ} \mathrm{S}$ has a high variability in physical and chemical properties and represents an ecotone of high biological diversity. Peaks of phytoplankton biomass have been found associated with frontal structures (Gayoso \& Podestá 1996).

Biological information from two main sources has been reviewed: 1) Papers published in local, regional, or international journals, and 2) Recently updated bibliographic databases related to this area (López et al. 1999). In addition, the present authors' knowledge of antecedents and that deriving from discussions with colleagues on relevant published and unpublished information have also been used to some extent.
The information for the plankton, nekton and benthos in each of the 3 main areas, the littoral (supralittoral to $10 \mathrm{~m}$ depth), shelf (10-200 m), and "open ocean" (> $200 \mathrm{~m}$ ), is reported separately. For the benthos, the littoral zone was further divided into sandy and rocky shores, in view of the significant research effort derived from these ecosystems in Uruguay.

Nomenclature follows Boltovskoy et al. (1999) for plankton and Cousseau et al. (1998) and Ponce de León (2000) for nekton.

\section{THE KNOWN}

\section{PlanKTON}

The South Atlantic Ocean hosts 50-100\% of known zooplankton species, depending on the taxa considered. However, for a few groups (the Copepoda, Mysidacea, and Acantharia), the fraction is lower (<25\%) (Boltovskoy et al. 1999). Between ca. $30^{\circ} \mathrm{S}$ and $45^{\circ} \mathrm{S}$, the confluence of $\mathrm{BC}$ and $\mathrm{FC}$ results in a biogeographic Transition Zone off Uruguay which affects the large scale distribution pattern of most marine organisms (Boltovskoy et al. 1999). The occurrence of warm and cold water biota results in a somewhat lower diversity for taxa such as the Foraminifera, Chaetognatha, Salpida, Apendicularia, and Ostracoda, which is a deviation from the usual pattern of higher diversity at lower latitudes (Boltovskoy et al. 1999, Woodd-Walker et al. 2002).

Taxonomic studies and descriptions of the distribution in space/time have been the most frequent investigations in this area, in contrast to biological and process-oriented studies. Research efforts have been mostly directed towards the coastal areas. About $50 \%$ of the published studies were carried out in the nearshore area $(<10 \mathrm{~m})$, while the remaining $50 \%$ were conducted over the shelf, shelf-break, or deeper waters. The majority of the studies developed by Uruguayan scientists were in shallow waters; those at depths $>10 \mathrm{~m}$ were undertaken mostly by research groups from neighboring countries.

Coastal plankton: Euryhaline diatoms and dinoflagellates dominate the phytoplankton community in mixohaline and polyhaline waters, whereas, in fresh and oligohaline areas of the RdlP, the 
Chlorophyceae and Cyanophyceae are also important; among the latter, Microcystis aeruginosa forms harmful algal blooms (De Leon \& Yunes 2001). Phytoplankton biomass is highly variable (0.32-15.0 mg chl-a.l-1 (Bazigaluz 1981, Cervetto et al. 2002), and is presumed to respond to changes in nutrient / light gradients modulated by the mixing of fresh and marine waters. A sharp reduction in turbidity (turbidity front) occurs just downstream from the upper reach of the salt wedge. The highest rate of phytoplankton production can be expected to occur seaward of the turbidity front as a result of improved light availability (Blanco 1989). This zonation within the RdlP is also reflected in the microplankton community structure (Souto 1974). Recent estimates by Gómez et al. (2001) suggest moderate to high productivity levels strongly influenced by the light regime.

In the coastal zone outside the influence of the RdlP, research on phytoplankton has been conducted in the Laguna de Rocha, an extremely shallow coastal lagoon. Studies have dealt with taxonomy and distribution in space/time (Conde et al. 1999), paleoecological reconstruction based on diatom assemblages (García et al. 2001, 2002, García \& Witkowsky 2002), and rate-process and functional studies involving light, nutrients, and UV modulation of primary production. Phytoplankton, epiphyton, and phytobenthos contribute to the high production of this ecosystem, the phytoplankton being the most efficient in terms of photosynthetic efficiency. Lagoon/ocean water exchange affects the optical characteristics and nutrient content of the water altering the limiting factors for primary production and modulating UV penetration in the water column (Conde 2001, Conde et al. 2002). The few zooplankton studies conducted within the RdlP indicate a low diversity dominated by small copepods (Acartia tonsa, Paracalanus parvus, Parvocalanus crassirrostris, Oithona spp.), mysids (Neomysis americana), and gelatinous plankton (ctenophores Mnemiopsis maccrady and Liriope tetraphylla) (González 1972, Milstein \& Juanicó 1985). Ctenophores dominate macroplankton biomass during the warm season, and tend to aggregate near the mouth of the estuary at the surface salinity front where, has been suggested, they play an important trophic role (Mianzán et al. 1996, Mianzán \& Guerrero 2000). Species richness tends to increase from Montevideo (salinity range 3-10;
Guerrero et al. 1997, Nagy et al. 1997) to Punta del Este (salinity range 20-30) with the addition of taxa like chaetognaths (Saggita friderici, S. bipunctata S. helenae, and S. hispida), cladocerans (Podon polyphemoides, Evadne normandii) and copepods (Ctenocalanus spp., Euterpina acutifrons, Centropages velificatus, plus others) (Milstein \& Juanicó 1985, Bastreri et al. 1988 (Fig. 2). This spatial pattern is likely to be highly dynamic and associated with the mixing and advection of water masses over short time-scales (i.e. hourly to fortnightly), as found for the Solís Grande river estuary, a sub estuary of the RdlP. There, a time-intensive sampling design showed a community dominated by a few copepod species (Cervetto 1987), controlled mainly by large scale physical forcing on a 15 day scale determined by the dominant wind pattern (Gómez et al. 2000) and by biological rhythms on a diel scale (vertical migration) (Calliari et al. 2001).

RdlP waters of Uruguay are also important spawning and nursery areas for several fish species. Plankton studies and analysis of the gonadal cycle of adult individuals indicate that the estuarine frontal zone close to the Uruguayan coast is probably the most significant spawning area for the white croacker (Micropogonias furnieri) and menhaden (Brevoortia aurea) (Macchi et al. 1996, Macchi 1997, Acuña et al. 1997, Vizziano 2001, see Mianzán et al. 2000). Nursery areas seem to be located very close to the coast, e.g.in the surf zone of sandy beaches or bays and small sub-estuaries (Martínez \& Retta 2001). The saline frontal structure could provide a retention mechanism for larvae similar to that proposed for other areas (Sinclair 1988, Sinclair \& Iles 1989) but the retention/advection mechanisms are still largely unknown, as are as most aspects of larval ecology. Deeper areas of the RdlP and inner shelf are spawning grounds for other estuarine-related commercial fishes like Cynoscion guatucupa, Macrodon ancylodon, and Brevoortia sp. (Hubold \& Ehrlich 1981, Acuña \& Viana 2001).

Shelf and open ocean: Knowledge of the plankton of shelf seas and shelf-break waters is similar to that described for the coastal region, though some general mechanisms have been proposed to relate phytoplankton development to the fertilizing effect of circulation patterns (see review in Odebretch \& Castello 2000). In addition to the taxonomic stud- 
ies of microplankton and phytoplankton groups (Müller-Melchers 1959, Balech \& Souto 1980a, b, Akselman 1985, Lange \& Mostajo 1985), a limited number of investigations have dealt with the relation between community structure and environmental conditions (Elgue et al. 1987, 1990, Negri et al. 1988, Mesones 1991, Gayoso 1996, Gayoso \& Podestá 1996). The distribution of the phytoplankton assemblage off the RdlP follows a zonation pattern that reflects the mixing of water masses with differing nutrient contents along a coast-ocean gradient (Negri et al. 1988): an estuarine-influenced community immediately offshore from the RdlP is followed by coastal, transition, and subantarctic assemblages. This highly dynamic pattern is linked to the hydrographic variability, a view supported by the dominance of diatoms (Mesones 1991) or di- noflagellates and cocolithophorids (Gayoso 1996) at different times in the same area. Shelf waters may host high phytoplankton biomasses (up to ca. 10 mg. $\mathrm{l}^{-1}$ (Negri et al. 1988, Mesones 1991), and harmful algal blooms have been reported over wide areas of the shelf (Negri et al. 1992, Brazeiro et al. 1997). Over the outer shelf and slope, the interplay of BC and FC determines the hydrography and the characteristics of the biota (Boltovskoy et al. 1999 and references therein). Diatoms (Thalassiosira, Lauderia, and Chaetoceros), dinoflagellates ( $G y$ mnodinium, Polikiros, Gyrodinium), and unidentified flagellates dominate the phytoplankton, and their abundance seems to be strongly coupled to surface fronts and hydrographic features like eddies, filaments, and meanders created by the mixing of BC and FC (Gayoso \& Podestá 1996).

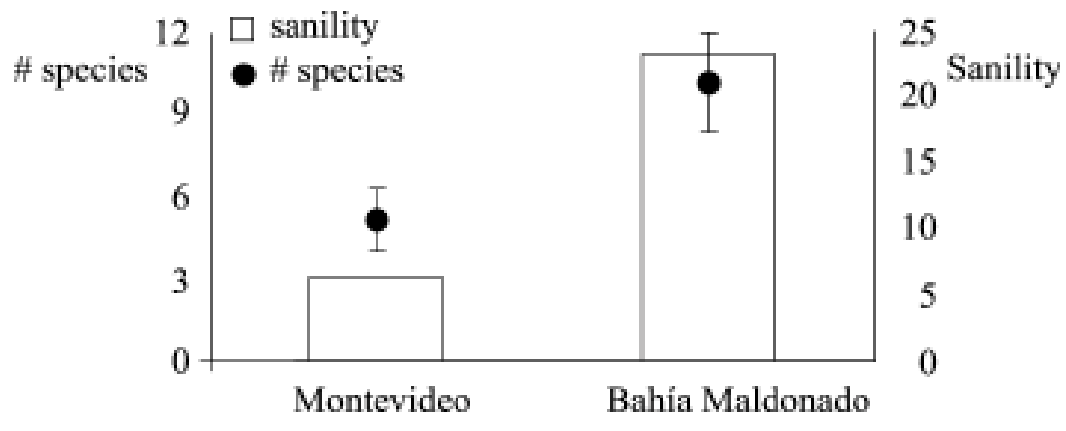

FIGURE 2. Mean number of copepod species and salinity recorded at two sites over the salinity gradient of the Río de la Plata: Montevideo and Bahía Maldonado (Punta del Este). Data from Montevideo are from Cervetto et al. (1988) and data from Bahía Maldonado are from Milstein \& Juanico (1985).

FIGURA 2. Número promedio de especies de copépodos y salinidad registrados en dos sitios a lo largo del gradiente salino del Río de la Plata: Montevideo y Bahía Maldonado. Los datos de Montevideo son tomados de Cervetto et al. (1988) y los de Bahía Maldonado son tomados de Milstein \& Juanico (1985).

According to the synthesis by Odebrecht \& García (1997) and Odebrecht \& Castello (2000), continental runoff (from Lagoa dos Patos and RdlP) and turbulence over shallow waters control nutrient inputs to the inner shelf (Ciotti et al. 1995, Odebrecht \& Djurfeldt 1996). This influences phytoplankton development which, during the productive season, reduces the nutrient levels seaward of the chlorophyll maximum (Negri et al. 1992, Abreu et al. 1995,
Ciotti et al. 1995). Over the outer shelf, fertilization is mainly due to the upwelling of nutrient-rich SAW caused by wind-driven cyclonic vortices, shelf and slope topography, and current shear (Hubold 1980a, b, García 1997, Odebrecht \& Castello 2000), which enhance primary production (Niencheski \& Fillmann 1997, Odebrecht \& García 1997) and abundance (Gayoso \& Podestá 1996).

Taxonomic approaches and spatial patterns in the 
distribution of assemblages were the focii of zooplankton investigations (i.e. Esnal 1970, 1978, Ramírez 1970, 1973, Montero 1975, Ramírez \& Zamponi 1980, Boltovskoy 1973, Goberna 1986, 1988, Gómez 1987, Amaral et al. 1997). The shelf zooplankton, dominated by copepods, is more species-rich than the coastal and estuarine populations. In-depth taxonomic reviews of most groups can be found in Boltovskoy et al. (1999). Distribution studies have mainly involved copepods and the results appear to be consistent with the phytoplankton zonation pattern referred to earlier (Fernández et al. 1994, Santos \& Ramírez 1991). Both copepod and phytoplankton distributions reflect the various water masses present as described by Carreto et al. (1986). An increase in individual copepod size from the coast to the open ocean has been documented (Fernández et al. 1994); this probably results from changes in species composition over that gradient. At the southern end of the Brazilian shelf $\left(27-35^{\circ} \mathrm{S}\right)$, Resgalla et al. (2001) found that zooplankton was affected by offshore Ekmann transport and that the highest biomass occurred off the southernmost coast during summer and autumn. Biomass peaks corresponded to gelatinous plankton (mainly salps) whose low energetic value, high grazing capabilities, and significant contribution to the downward export of organic matter could strongly influence the structure of the pelagic ecosystem (Montú 1997, Resgalla $e t$ al. 2001). A preliminary assessment also suggested that zooplankton is a major food source for the juveniles of many fish species (Goberna 1987).

The ichthyoplankton of the shelf and shelf-break waters is rather rich, comprising about 88 species (Sinque \& Muelbert 1997). Most efforts have been directed towards describing the distribution and general ecology of Engraulis anchoita, the dominant small pelagic species, and Merluccius hubbsi, the major demersal fishery resource. Spawning grounds of these species are associated with frontal areas (Mantero 1986, Ciechomski \& Sánchez 1986, Ehrlich \& Ciechomski 1994, Ehrlich 2000). E. anchoita in particular is probably the better studied species in relation to different aspects of its early life stages (Sánchez 1991). Ichthyoplankton studies were also conducted with other clupeoids (Brevoortia pectinata, Anchoa marinii, Lycengraulis grossidens; Weiss et al. 1976, Weiss \& Souza 1977, Hubold \& Ehrlich 1981), Stomiiformes (Bonecker
\& Hubold 1990), and Myctophidae (Sinque \& Muelbert 1997).

\section{NEKTON}

The first studies of the ichthyofauna of the RdlP and adjacent waters were performed by Holmberg (1888), Berg (1895), Devincenzi (1920a, 1920b, 1924, 1933, 1939a, 1939b), Devincenzi \& Barattini (1926, 1928), Devincenzi \& Legrand (1936, 1940), and De Buen (1950). A systematic key and extensive list of species were published by Ringuelet \& Aramburu (1960) and Menni et al. (1984). A complete list of fish species present permanently or occasionally in the area (360 species) has been provided by Cousseau et al. (1998).

The fish assemblages of the RdlP and its oceanic front are parts of those present along the continental shelf and slope between $34^{\circ} \mathrm{S}$ and $38^{\circ} \mathrm{S}$ at up to 1.000 $\mathrm{m}$ depth. The ichthyofauna inhabiting this area result from the influence of the 2 main zoogeographic provinces in the Southwestern Atlantic - Magellanic (subantarctic) and Argentinian (subtropical) (López 1963, 1964, Menni 1983, Menni \& López 1984, Menni \& Stehmann 2000) - which exhibit a large spatio-temporal variability during the year.

Río de la Plata and coastal waters. On the basis on 4 research cruises, Cousseau (1985) classified the fish of the RdlP according to their environmental preferences as freshwater $(n=7)$, stenohaline $(n=19)$, and euryhaline $(\mathrm{n}=58)$ species. More recently, Nión (1998), using bibliographic surveys and the results of cruises, suggested that, in the RdlP, there are 174 freshwater species, 53 marine species, and 42 visiting marine species. The most abundant species which constitute the basis for important fisheries in the region undergo seasonal trophic or reproductive migrations related to changes in the hydrographic conditions (Bellisio et al. 1979, Ciechomski et al. 1979, Cousseau et al. 1979, 1986, Ehrhardt et al. 1977a, 1979, Nión 1985, Ubal 1986, Otero 1986, Otero et al. 1982, 1986, Rey \& Grunwaldt 1986, Arena et al. 1986, Fernández \& Norbis 1986, Simonazzi \& Otero 1986, Angelescu \& Prensky 1987, Ubal et al. 1987a, 1987b, Acuña et al. 1992, Norbis et al. 1992, Norbis \& Galli 1999). The distribution, abundance, and population structure of chondricties were analyzed by Meneses (1999) and Paesch (1999) for the RdlP and continental shelf, respectively. 
Shark fisheries analyses were reported by Arena et al. (1974), Marín and Puig (1986) and Nión (1999) and the composition of catches and effects of longline fisheries on pelagic sharks have been described by Marín et al. (1998), Domingo (2000), Domingo et al. $(1996,2002)$ and Hazin et al. (in press).

In the coastal zone, teleosts of the family Sciaenidae (Micropogonias furnieri, Cynoscion guatucupa, and Macrodon ancylodon) are dominant out to a depth of $50 \mathrm{~m}$. Abella et al. (1979) found 7 species in the rocky intertidal zone and in sandy beaches, with 2 species in common, Micropogonias furnieri and Pogonias cromis. Nión (1985) argued that the coastal system provides the principal nursery grounds for the former. The main coastal species spawn from October to March along the Uruguayan coast. Histological analysis showed that they do so seasonally, partially spawning with group-synchronised ovarian maturation (Arena \& Hertl 1983, Vizziano \& Berois 1990, Pravia et al. 1995, Macchi \& Christiansen 1992, 1996, Macchi et al. 1996, Acuña et al. 1997, Acuña et al., 2000; Viana et al., 2000) which, in turn, is related to environmental variability (Acuña \& Viana 2001, Vizziano 2001; Vizziano et al. 2001).

Shelf and open ocean. The species Merluccius hubbsi, Cheilodactylus bergi, and Helicolenus dactylopterus lahillei are the most abundant resources between 50 and $400 \mathrm{~m}$ depth. The hake (M. hubbsi) and the hawkfish ( $C$. bergi) seasonally migrate in relation to changes in the oceanographic conditions, spawning during autumn/winter on grounds in the Argentinian-Uruguayan Common Fishing Zone (Ciechomski \& Weiss 1974, Ehrhardt et al. 1977a, 1979; Grundwaldt 1986, Erlich \& Ciechomski 1986, Christiansen et al. 1986, Angelescu \& Prensky 1987, Ubal et al. 1987c, Olivieri \& Christiansen 1987, Norbis 1998, 1999a). The growth and mortality of hawkfish and hake were studied by Norbis (1992) and Lorenzo (1999a, 1999b). Nión et al. (1986) described a multispecific nursery ground over the inner shelf, and an important hake nursery area on the Uruguayan continental shelf in autumn and spring was found by Rey et al. (1996), Norbis et al. (1999), Mantero \& Errea (1999) and Errea et al. (1999); juveniles of $C$. bergi were also detected here (Galli \& Norbis, 1992). The relationships between hake nurseries and oceanic fronts were analysed by Norbis \& Severov (1999) and Severov (1999).
The anchovy (Engraulis anchoita), the horse mackerel (Trachurus lathami), the mackerel (Scomber japonicus), and the blue fish (Pomatomus saltatrix) are the most abundant pelagic species (Brandhorst et al. 1971a, 1971b, 1971c, Ehrhardt et al. 1977b, Nión \& Ríos 1991, Alheit et al. 1991). Other species such as Thunnus alalunga, Thunnus albacares, Thunnus obesus, and Xiphias gladius are also important components of the pelagic oceanic system (Ríos et al. 1986, Nión \& Ríos 1991, Marín et al. 1998, 2000). An analysis of the principal groups of demersal fishes by latitude, depth, and bottom type was presented by Abella et al. (1979); this included 80 genera and more than 140 species. Various authors (Menni \& Gosztonyi 1982, Ishino et al. 1983, Angelescu \& Prensky 1987, Prensky \& Sánchez 1988, Norbis 1993, 1999b, Díaz de Astarloa et al. 1999, Menni \& Stehmann 2000) addressed different aspects of the demersal fish's assemblages over the continental shelf, mainly related to composition, abundance, diversity, and how these depended upon latitude, depth, temperature, and salinity. Stomach content analyses for coastal species are scarce (Mora \& Pintos 1980, Puig 1986, Leta 1987, Masello et al. 2001). Possible trophic relationships in the coastal system were discussed by Olivier et al. (1968), while some were demonstrated for the hake foodweb (principally involving zooplankton, anchovy, and squid) (Ubal, 1986; Angelescu \& Prensky, 1987 and Galli, 1999). An analysis of the feeding of elasmobranch fish was performed by Paesch (2000).

Marine mammal species that live in or visit the area include Arctocephalus australis, Otaria byronia, Pontoporia blainvillei, Tursiops truncatus, and Orcinus orca among the former, and Arctocephalus tropicalis, Mirounga leonina, Balaenoptera musculus, B. physalus, B. borealis, Eubalaena australis, and Megaptera novaengliae among the latter (Ponce de León 1999). Research has focused mainly on sealion and fur seal populations (O. byronia and A. australis), and provided the basis for sustainable exploitation for many decades (Vaz Ferreira 1965, 1972, $1975 \mathrm{a}, \mathrm{b})$; there is now information regarding their ethology, growth, population dynamics, feeding, and interactions with artisanal fisheries (Vaz Ferreira 1987, Batallés et al. 1990, Lima \& Páez 1995, 1997, Lima 1998, Szteren 1999, Ponce de León et al. 2000, Szteren \& Páez 2002). Attention was also paid to the accidental capture of the Río de la Plata dolphin ( $P$. 
blainvillei), an endemic species of the RdlP and neighboring areas (ca. 18³0'-42³0'S), for which systematic records since the 1970s are available (Praderi et al. 1989, Little et al. 1997). Furthermore, recent examinations of genetic variability in the dolphins suggest the existence of a Río de la Plata-Río Grande population different from that further north (Rio de Janeiro, Brazil), and south (Claromecó, Argentina) (Lázaro 2001).

\section{BENTHOS}

\section{Sandy beaches}

Sandy beaches dominate ocean and estuarine shorelines of the $670 \mathrm{~km}$ Uruguayan coast (UNESCO 1980). Currently available information is mainly for macroinfauna, both at the community and population levels, particularly on exposed ocean beaches. However, data are particularly scarce or absent for plankton, meiofauna, vagile megabenthos, and nekton of the surf zone, as well as for birds and subterrestrial fauna of the sand dunes.

Communities: Investigations have focused on the description of the structure, seasonal dynamics, and patterns of distribution of macroinfauna at spatial scales ranging from macro $(\mathrm{km})$ to meso (individual beaches). Escofet et al. (1979) provided general macroscale features of macroinfauna communities for sandy beaches of the Southwestern Atlantic coast from $29^{\circ}$ to $43^{\circ} \mathrm{S}$. Scarabino et al. $(1974,1975)$ documented general bionomic patterns and spatial variations of the macroinfauna in the upper littoral levels of the sandy beaches of Montevideo. Following the same approach, details about intertidal (Baccino 1984, Demichelli 1984) and sub-tidal (Demichelli 1984, 1985a) populations were provided for the macroinfauna inhabiting a semi-exposed sandy beach. Demichelli (1985b) also characterized the sub-tidal community structure of an exposed Atlantic sandy beach. Quantitative macroscale patterns were formerly determined through a snapshot study covering a complete range of dissipative-reflective categories of Atlantic sandy beaches (Defeo et al. 1992a).

Initial studies directed towards distinguishing faunal zonation across beaches were qualitative in nature (Scarabino et al. 1974, 1975, Demichelli 1984, 1985a, b, Baccino 1984) or based on a very short time scale (one sampling date) (Defeo et al. 1992a). More recent work has adopted a quantitative approach with monthly samplings for up to a year on exposed beaches of the Atlantic coast of Uruguay. These showed significant spatial variability in zonation with aperiodic and seasonal components (Brazeiro \& Defeo 1996, Giménez \& Yannicelli 1997).

Alongshore variations in community structure were examined mainly to assess the spatial and temporal effects of a freshwater discharge on the macroinfaunal community and its habitat in a sandy beach of Uruguay (Lercari \& Defeo 2002).

Populations: Studies at the population level were targeted at answering specific questions, notably those related to medium/long-term variations in abundance, responses of the species to beach morphodynamics, dynamic variations in abundance in the across and alongshore axes, responses of the species to disturbances (e.g. harvesting and freshwater discharge), population dynamics (e.g. growth, mortality, and recruitment), and assessment of the relative contribution of biotic and abiotic factors regulating populations.

Abundance, demography, and population dynamics were the main factors studied in the yellow clam, Mesodesma mactroides (Defeo 1993, Seijo \& Defeo 1994, Brazeiro \& Defeo 1999). Data from an 8 year study included an experimental manipulation of the fishing effort based on the closure of the clam fishery for 32 consecutive months (Defeo 1996a, 1998, Lima et al. 2000, Castilla \& Defeo 2001). A longterm analysis of the structure of a population of another sandy beach bivalve, the wedge clam Donax hanleyanus, was carried out by Defeo \& de Alava (1995) and Seijo et al. (1994).

Growth, mortality, and recruitment parameters were estimated for different sandy beach populations using a wide range of frameworks in order to test specific hypotheses (Defeo 1985b, de Alava \& Defeo 1991, Arreguin et al. 1991, Defeo et al. 1988, 1992b, c, 2001, 2002, Brazeiro \& Defeo 1999, Gómez \& Defeo 1999). Reproductive biology studies (Masello \& Defeo 1986) were useful complements to those of population dynamics (Defeo et al. 1992b).

Alongshore gradients were quantified in sandy beach populations of Uruguay (Defeo 1985a, Defeo et al. 1986, 1988, de Alava and Defeo 1991, Riestra et al. 1996, Giménez \& Yannicelli 1997, 2000). Species- 
specific behavioral responses to swash climate, manifested in swimming ability, burying, and orientation to directional flows, were addressed by Yannicelli et al. (2001, 2002). The across-shore population structure and abundance of sandy beach macroinfauna was recently derived from design-based (stratified random sampling) and model-based (geostatistics, kriging) approaches (Defeo \& Rueda 2002), and the effect of morphodynamics on the life history traits of such populations was investigated by Defeo et al. (1992a, 2001, 2002), McLachlan et al. (1995), and Gómez \& Defeo (1999). The role of sediment characteristics and potential interactions in determining the abundance and distribution patterns of the cirolanid isopods Excirolana armata and Excirolana braziliensis in sandy beaches of Uruguay have also been examined (Defeo et al., 1997).

In addition to natural biotic and abiotic factors, various forms of human-induced perturbations affect the nearshore, benthic environment in exposed sandy beaches, notably fishing, building, and pollution coming from discharges from wide plain basins used for agriculture and cattle rearing, and subjected to agro-chemicals (Defeo \& Lercari 2000, Brazeiro 2000, Lubchenco et al. 1995).

Species supporting current fishing activities (Mesodesma mactroides) or likely to do so in the future (Donax hanleyanus, Emerita brasiliensis); have been studied in Uruguayan beaches (Defeo 2002). These have intertidal distributions but most are centered in the swash zone or shallow sub-tidal area. Recreational fisheries on sandy coasts have been shown to be extremely difficult to manage since the numbers of fishermen cannot usually be controlled and measures to prevent over-exploitation are based on size and catch limitations and seasonal/ area restrictions (Defeo 1987, 1989a, b, Defeo et al. 1991a, 1993, Seijo \& Defeo 1994, Seijo et al. 1994). A successful example of improving the management of coastal shellfisheries through natural repopulation, rotation of areas, and the allocation of property rights (individual quotas) was documented for the small-scale fishery of $M$. mactroides (Defeo 1993, 2000). Experimental manipulation of the yellow clam fishery was used to evaluate changes in the overall abundance of harvested (M. mactroides) and unharvested (D. hanleyanus) bivalves, as well as in the processes regulating their population dynamics (Defeo 1996a, b, 1998: reviewed in McLachlan et al. 1996 and Castilla \& Defeo 2001).
The potential effects of freshwater discharge from a man-made canal on the wedge clam $D$. hanleyanus were analyzed as functions of time and space (alongshore variation) (Defeo \& de Alava 1995, 2002). Similar studies were carried out on sandy beach gastropods (Defeo et al. 1996) and the mole crab Emerita brasiliensis (Lercari \& Defeo 1999, Defeo $\&$ Lercari 2000). Further work demonstrated the spatial effects of freshwater canal discharge on the habitat and resident macrobenthos of a Uruguayan exposed sandy beach through a combined analysis of communities, populations, and the surrounding habitat (Lercari \& Defeo 2002). Overall, it must be concluded, future research on sandy beach populations should include human activities as important factors affecting long-term trends.

\section{Marine rocky shores}

Rocky habitats occupy a very narrow portion of the Uruguayan coast. Basically, the littoral fringe is dominated by extensive sandy arcs delimited by rocky headlands or freshwater discharges. However, these rocky ecosystems sustain a rich biological diversity, and important artisanal fisheries (e.g. blue mussels).

The biodiversity of rocky intertidal and shallow subtidal habitats is comparatively well known, with important differences between taxonomic groups (Masello \& Menafra 1996, Brazeiro 2000). Molluscs, Decapoda (i.e. Amaro 1965, Scarabino et al. 1975, Maytía \& Scarabino 1979, Batallés 1983, Riestra et al. 1992, Riestra 1999) and algae (Coll 1979, Méndez 1982) are the best described taxonomic groups, while others like amphipods, isopods and polychaetes, are poorly known.

The geographic and local distributions (zonation patterns) of the biota have been qualitatively described (Scarabino et al. 1975, Maytía \& Scarabino 1979, Neirotti 1981, Batallés et al. 1985). Community structure, including species richness and composition, is only well known at specific localities like Punta del Este, where relatively long term studies have been carried out (Riestra et al. 1992, Riestra \& Defeo 1994, Riestra 1999). On a larger geographical scale, the salinity gradient produced by the interaction between the RdlP and the Atlantic Ocean has been suggested as the main factor determining the variations in the distributional and compositional patterns (Maytía \& Scarabino 1979). 
In accordance with this hypothesis, a massive mortality of marine organisms on the Atlantic coast was ascribed to a fresh water intrusion from the RdlP (Riestra et al. 1997). On a more local scale, the effect of harvesting the blue mussel Mytilus edulis platensis on the macrobenthos was the only ecological factor studied in relation to community organization (Riestra et al. 1992, Riestra \& Defeo 1994, Riestra 1999).

Population patterns and processes such as abundance, growth, recruitment, and mortality have been studied only in the exploited population of the blue mussel (Mytilus edulis platensis) of Punta del Este (Abdala 1981, Berocay 1983, Batallés \& García 1984, Riestra \& Defeo 1994). The characteristics of this artisanal fishery have been very well documented (Arena et al. 1989a, b, Niggemeyer \& Masello 1992).

Basic information about an invader species, the bivalve Limnoperna fortunei, was reported by Scarabino \& Verde (1994). This exotic mussel is native to China and Southeast Asia and has been spreading in the RdlP since 1991, populating various types of hard substrates in freshwater and euryhaline zones.

\section{Estuarine habitats}

Estuarine benthic habitats are comprised of the RdlP estuarine system and associated subestuaries of the outer RdlP (e.g. the rivers Santa Lucía and Solís Grande) and a group of small estuaries located at river mouths and in coastal lagoons on the Atlantic coast (e.g. the Maldonado and Valizas rivers and Rocha and Castillos lagoons).

Information about species composition comes from quantitative sampling as well as qualitative observations and collections in several sites along the Uruguayan coast. These data are mainly for macrofauna and show that the benthic habitats are, in general, dominated by only a few species of crustaceans, molluscs, and polychaetes.

Information about species composition and patterns of distribution of the macroinfauna of RdlP were reviewed by Massello \& Menafra (1997) and Mianzan et al. (2000). On the Uruguayan coastline, only a few sites have been studied with respect to species composition, patterns of distribution, and community structure, namely Montevideo Bay (Danulat et al. 2002), the Solís Grande subestuary,
(Bier 1985, Muñiz \& Venturini 2001), Rocha lagoon and the Valizas stream (Nión 1979, Corbellini 1983, Cardezo 1989, Pintos et al. 1991, Jorcín 1993, 1999). Seasonal variations in macroinfaunal abundance in the Rocha lagoon and the Valizas stream were also studied by the previously named authors. An experimental study focused on the effects of eutrophication on the abundance of the macrobenthos (Arocena 2000), whereas another examined the benthic fauna in a highly contaminated area (Danulat et al. 2002).

Studies of the life history and ecophysiology of the estuarine macrobenthos made either in Uruguay or by Uruguayan scientists working elsewhere concerned the crab Chasmagnathus granulata and examined survival, growth, and osmoregulation in embryos (Giménez \& Anger 2001), adults (Holcman-Spector et al. 1973, Mañé-Garzón et al. 1974, Gnasso et al. 1978), and larvae (Giménez 2000, 2002, Charmantier et al. 2002).

\section{The continental shelf benthic ecosystem}

Taxonomic and faunal knowledge is limited and scattered for most groups of macrobenthos. Biogeographically, the fauna that inhabit the continental shelf ecosystem of Uruguay integrate components of the Magellanic, Argentinean and Indean Provinces (López 1964, Scarabino 1977, Menni \& Stehmann 2000). The few studies conducted at community level related to soft bottoms (Milstein et al. 1976, Cachés 1980, Masello et al. 1996, Venturini et al. 1999) or were part of an investigation of the feeding habits of commercially exploited stocks such as the croaker, Micropogonias furnieri (Puig 1986). Ecological studies of particular invertebrate groups are also few and restricted to molluscs (Olivier \& Scarabino 1972, Layerle \& Scarabino 1984), polychaetes (Elgue \& Faget 1986), and ophiuroids (Lucchi 1985). Information about benthic fish is, on the other hand, more abundant (Abella et al. 1979, Arena et al. 1993, Díaz de Astarloa et al. 1999, Paesch 1999, Fabiano et al. 2000a, Spinetti 2000, Paesch 2000, Meneses 1999, Menni \& Stehmann 2000). Research and commercial surveys of several megabenthic invertebrates provided preliminary information about the targeted species and their associated fauna. These species include the gastropods Zidona dufresnei and Pachycymbiola brasiliana (Fabiano et al. 2000b, Riestra et al. 2000), the blue 
mussel Mytilus edulis (Juanicó \& Rodríguez 1976, Amaro 1979), and the Patagonian scallop $Z y$ gochlamys patagonica (Defeo \& Brazeiro 1994, Defeo \& Gutiérrez 2000, Riestra \& Barea 2000, Riestra 2000).

\section{The slope and abyssal plain}

Here too, taxonomic and faunal data are scarce and restricted to those that resulted from 3 comprehensive surveys by research vessels - the Challenger ( 2 stations), the Atlantis II (macrobenthos of southern zone), and the Walther Herwig (megabenthos); all samples were from soft bottoms. The level of endemism reported for an important macrozoobenthic group (the Bivalvia Protobranchia) in this region is the highest among the deep-sea basins of the Atlantic Ocean (Allen \& Sanders 1997). Biogeographic affinities deduced from this group are enigmatic, with possible relations with the Angola Basin and southern Pacific (Allen \& Sanders 1997). Autoecological and biological knowledge exists only for a very few megabenthic species: the red crab Chaceon notialis (Defeo et al. 1989, 1991b, Defeo \& Masello 2000a, 2000b), the octopus Vosseledone charrua (Leta 1992), the starfish Bathybiaster herwigi (Scarabino 1983), some gastropods (Olivier \& Scarabino 1972), and skates (Menni \& Stehmann 2000).

\section{THE UNKNOWN}

\section{PlankTon}

Studies of plankton systematics and distribution in coastal areas shallower than $10 \mathrm{~m}$ have contributed disproportionately to the investigations. Physical processes and patterns of biological production in the pelagic zone are central to the understanding of the biogeography of marine life (Longhurst 1998, Woodd-Walker et al. 2002).

Thus, a functional approach to the study of these processes is strongly required to complement existing knowledge in this area. This will require multidisciplinary studies ranging from research on individual physiological responses to large-scale programs directed towards discerning physical-biological coupling processes, and should include laboratory, field, and modeling efforts.

Present understanding of the zonation patterns along environmental gradients within the RdlP (i.e. salinity, turbidity) is very fragmentary. Efforts are needed to investigate the forcing factors behind the patterns involving the identification of dominant or key species (sensu Verity \& Smetacek 1996), as well as the study of their life history traits, population dynamics, and responses to the variable environment. The characterisation of salinity tolerance ranges and how feeding and production vary with changes in environmental conditions are also important. Special attention must be given to frontal zones (within the RdlP as well as over the shelf), since they may represent zooplankton "hot spots" (sensu Paffenhöfer 2001).

Seasonal patterns of phytoplankton and zooplankton biomass and production are poorly known, asis how these variables are affected by environmental variability on different time-scales (e.g. coastal eutrophication and long-term increments in RdlP outflow; Nagy et al. 1997). There is a lack of time series of biological variables required to explore long-term trends and low frequency cycles related to environmental variability. An exception is a monitoring program focused on potentially toxic dinoflagellates being carried out at coastal sites (Méndez et al. 1997); it would be profitable to enhance this work by incorporating simple protocols for measuring phytoplankton and zooplankton biomass. There is also a strong need to build up a thorough picture of primary production and its temporal variability over the whole area, as well as of the factors which regulate production-light, nutrients, and grazing-which are likely to vary between the seasons and different areas (e.g. light limitation in the highly turbid waters of the RdlP vs. nutrient limitation over the shelf).

There is no information regarding trophodynamics within the plankton assemblage and the fate of locally produced organic matter. No estimations of ingestion rates have been made for any zooplankton group and the relative contribution of the small fractions (i.e. zooplankton $<200 \mathrm{~mm}$ ) to the total grazing pressure on phytoplankton has not been documented. Protozoan plankton (ciliates and flagellates), which are well known to reach high densities in estuarine areas (Smetacek 1981, Gifford \& Dagg 1988, Day et al. 1989, Lalli \& Parsons 1997) may play a crucial role in the cycling of organic matter and making it available to the grazer food chain. Potentially dominant mesoplankton grazers in the 
RdlP (e.g. Acartia tonsa) are especially able to switch from herbivory to carnivory (Kiorboe \& Sáiz 1995, Saiz $\&$ Kiorboe 1995). Given the high availability of particulate organic matter, it would be relevant to estimate the significance of the algal diet at different seasons and areas in order to assess the coupling between primary and secondary production.

Future research should incorporate modelling efforts to condense empirical results and guide further observations and experimentation. In this respect, models on physical-biological coupling would be particularly interesting, considering that several physical models for the RdIP have been proposed or are under development.

\section{NEKTON}

Studies of the littoral coastal system are scarce and those existing have not adopted an integrated ecosystem approach. Fish and their role in the surf-zone of sandy beaches are largely unknown. There is a lack of information on the taxonomy and distribution of clupeids, myctophids, and other groups. Data on feeding habits and trophic ecology are scarce and mainly limited to studies of commercially important species. Life-cycles and population dynamics of the majority of groups are incompletely known. The relationships between spawning types, spawning areas, environmental variability, and the structure of the spawning stock during the reproductive period have also received little attention. Information regarding the growth of juvenile fish in relation to environmental variability and feeding availability is limited. Also, the effect of fisheries on diversity and community structure is largely unknown.

\section{BENTHOS}

\section{Sandy beaches}

Information is particularly scarce and sometimes absent for the plankton, meiofauna, vagile megabenthos, and nekton of the surf zone, as well as for birds and the sub-terrestrial fauna inhabiting sand dunes. In this context, an ecosystem approach is needed for modeling interrelations between different components of food webs as well as the nature and extent of the networks of interactions between species. Other processes and mechanisms (e.g. predation, comensalism, parasitism, and mutualism) that affect the structure and functioning of sandy beach populations and communities are still unknown. The sub-tidal fringe has been little explored, particularly with regard to basic knowledge about systematics and the general characteristics of the fauna at the community and population levels.

Long-term, large-scale monitoring of the structure and dynamics of sandy beach macroinfauna, as well as the concurrent effect of the estuarine gradient (RdlP) and morphodynamics on the fauna inhabiting these systems needs to be initiated. Knowledge of biodiversity gradients is fragmentary, particularly for certain taxonomic groups (e.g., components of the meiofauna and polychaetes) in fields such as taxonomy and systematics, as well as the inherent characteristics of their life histories. Furthermore, the macroecology of population dynamics and biogeographic patterns in life histories have not been adequately assessed in sandy beach ecology (Defeo \& Cardoso 2002).

Little is known about the dispersive abilities of meroplanktonic larval phases of sandy beach macrofauna and the mechanisms influencing larval distribution are poorly understood (Defeo 1996b). Research should focus on planktonic stages and the role of near-shore hydrodynamics in settlement processes. This could determine the degree to which population dynamics is related to the arrival rates of larvae rather than to post-settlement processes. Physical oceanographic information related to larval dispersal would be of importance in this context.

Recent results obtained by Uruguayan scientists support the view that beach morphodynamics may not be the primary factor affecting the life history traits of the macrofauna. The fact that unsimilar responses of populations could also result from locally adapted genotypes or a combination of plastic and genetic responses should be addressed through genetic studies on a macroscale.

Laboratory evidence is not extensive enough to reflect the variety of environmental regimes found at particular sites and their effects on benthic fauna. The physiological factors controlling species distribution and abundance need to be addressed together with ethological studies in order to evaluate the relative contributions of the factors influencing sandy beach fauna.

The exploitation of beach clams is often restricted by their accumulation of toxins such as those associated with certain algal blooms (Defeo \& 
Scarabino 1990); these can cause mass mortalities of clams and/or render them unsafe for human consumption. This limits the potential utilization of many stocks and creates the need for careful monitoring and management. As human impacts on coastal waters continue, blooms of toxin-producing phytoplankton could increasingly affect filter feeders. This should be a focus for future studies.

Despite their potential importance, very little is known about the consequences of natural or human-induced disturbances on the structure and dynamics of sandy beach populations and communities. Different approaches are needed to perform well-designed experimental and field studies directed towards critically assessing environmental impacts in these fragile ecosystems. This research should be complemented by laboratory (microcosm) experiments directed to determine the ecophysiological effects of pollutants and responses to abiotic factors.

Spatial and temporal variations in growth, mortality, and recruitment rates in sandy beach populations may be partially related to density-dependent processes (Defeo 1993, 1998). Future work should emphasize scale-dependent experimental manipulations of abundance. Moreover, the spatially discrete analysis of sandy beach populations, their surrounding environment and, eventually, the fishery will be a useful means for monitoring changes in abundance and structure, as well as in population dynamics parameters and environmental variables. An integrated approach to develop a comprehensive management scheme could be of the utmost importance for impact assessment studies (Defeo et al. 1991, 1993, Seijo \& Defeo 1994, Lercari $\&$ Defeo 1999).

\section{Marine rocky shores}

Descriptions of the biodiversity of rocky coastal habitats are scarce and completing our understanding of this biota will require great effort for some taxonomic groups, especially those inhabiting the mussels domain such as the Amphipoda, Isopoda, Polychaeta, Cnidaria, Turbellaria, Nemertea, and Nematoda.

The description of community patterns is in its early stages. Quantitative research on the relationship between different community traits (species richness and composition, abundance distribution) and environmental factors (exposure, habitat complexity, energy input, seascape configuration, pollution) is needed to understand community structure. The dynamic aspects of these communities, such as extinction and colonization rates, are unknown. The processes and mechanisms underlying the community structure are also far from being understood. Natural and field experiments would provide useful information. At the population level, only the demography of the blue mussel is relatively well known. There is no similar information for other species on rocky shores. Ecosystem studies of food webs, productivity, and the fluxes of particulate matter are nonexistent. Information useful for conservation purposes like conservation status, the level of endemism, and the rarity of species, or the localization of "hot-spots" in terms of high species richness or degree of endemism, are not available for Uruguayan rocky shores.

\section{Estuarine habitats}

Taxonomic and faunal data for benthic meiofauna and microfauna are similarly meagre. Again, basic knowledge such as patterns of distribution and community structure on a macroscale as well as temporal variability in abundance at most estuarine sites is not available. A research program that combines sampling and experimental approaches needs to be initiated in order to understand how the estuarine communities of the Uruguayan coast are structured and discover the similarities with and/or differences from other populations in the region; this should include an evaluation of the role of presettlement processes (e.g. larval transport and survival in the field) and postsettlement factors (predation, competition, physical stress) which affect species distribution. Similar requirements hold for ecosystem studies since these species are the prey of several fish; this could influence the transfer of nutrients and organic matter between the bottom and the water column.

\section{The continental shelf benthic ecosystem}

Taxonomic and faunal knowledge is inadequate for most groups of the macrofauna and there have been no studies of the meiobenthos or microbiology. Comprehensive research at the community and population levels is lacking, particularly for rocky bottoms. Community approaches have seldom been used for soft and, especially, hard bottoms, and biological, ecological, and biogeographical data are unknown for most species. The effect of fishing on the habitat and fauna inhabiting benthic ecosystems of the continental shelf remains to be examined. 
TABLE I. Summary of the degree of knowledge reached for the different groups and habitats in Uruguayan waters, and recommendations for future research. 1=unknown or very poorly known; $2=$ insufficiently known; $3=$ relatively well known. $\mathrm{ES}=$ estuaries, $\mathrm{RS}=$ rocky shores, $\mathrm{WA}=$ whole area, $\mathrm{SH}=$ shelf, $\mathrm{SB}=$ shelf-break and abyssal plain.

TABLA I. Resumen del grado de conocimiento alcanzado para los diferentes grupos y ambientes de aguas uruguayas, y recomendaciones para próximas investigaciones. $1=$ desconocido o muy poco conocido; $2=$ parcialmente conocido; $3=$ relativamente bien conocido. $\mathrm{ES}=$ estuaries, $\mathrm{RS}=$ rocky shores, $\mathrm{WA}=$ área entera, $\mathrm{SH}=$ plataforma, $\mathrm{SB}=$ shelf-break and abyssal plain.

\begin{tabular}{|c|c|c|c|c|c|c|}
\hline & & \multicolumn{2}{|c|}{ Littoral } & \multirow[t]{2}{*}{ Shelf } & \multirow{2}{*}{$\begin{array}{c}\text { Shelf-break \& } \\
\text { deep ocean }\end{array}$} & \multirow[t]{2}{*}{ Recommendations } \\
\hline & & Beach & $\begin{array}{c}\text { Coast }<10 \mathrm{~m} \& \\
\text { estuaries }\end{array}$ & & & \\
\hline \multirow{3}{*}{ Plankton } & Taxonomy & 1 & 2 & 2 & $1-2$ & \multirow{3}{*}{$\begin{array}{l}\text { Taxonomy,distribution } \\
\& \text { processes } \\
\text { over the WA }\end{array}$} \\
\hline & Patterns & 1 & 2 & 2 & $1-2$ & \\
\hline & Processes & 1 & 1 & 1 & 1 & \\
\hline \multirow{3}{*}{ Benthos } & Taxonomy & 3 & $1-2$ & $1-2$ & 1 & \multirow{3}{*}{$\begin{array}{c}\text { Micro-meiofauna (WA), } \\
\text { macrofauna } \\
(\mathrm{ES}, \mathrm{SH} \& \mathrm{SB}) \\
\text { WA } \\
\text { WA }\end{array}$} \\
\hline & Patterns & 3 & $1-2$ & 1 & 1 & \\
\hline & Processes & 2 & 1 & 1 & 1 & \\
\hline \multirow{3}{*}{ Nekton } & Taxonomy & 1 & 3 & 2 & 2 & \multirow{3}{*}{$\begin{array}{c}\text { For selected groups } \\
\text { Interactions between } \\
\text { components \& anthropic } \\
\text { effects } \\
\text { Population dynamics, } \\
\text { environmental effects } \\
\& \text { trophodynamics }\end{array}$} \\
\hline & Patterns & 1 & 2 & 2 & 1 & \\
\hline & Processes & 1 & 2 & 2 & 1 & \\
\hline
\end{tabular}

\section{The slope and abyssal plain}

Biotic aspects of the slope and abyssal plain are scarcely known, particularly for the northern zone of Uruguayan waters and the rocky bottoms. There have been no studies of the meiobenthos or microbiology, or of the macro- and megabenthos. Biogeographical issues and the specific characteristics of the life history traits of most species are unknown. A general biogeographic scheme has not been developed.

\section{CONCLUSION}

Table I summarises the known and the unknown aspects of marine life in Uruguayan waters. Future research will need to cover a wide spectrum of subjects and the proposals here may appear as rather ambitious. They will certainly take several years to consolidate. Research topics common to different groups include taxonomy, analysis of community structure on the macroscale and its temporal variability in relation to environmental gradients, population dynamics, trophodynamics, and the effects of human intervention on ecosystems. Issues such as meroplankton ecology and the fate of pelagic production may serve as links between benthic and planktonic studies; this is also the case in trophodynamical aspects of the early life stages of fish which involve the transfer of energy and matter between plankton and nekton. Finally, the incorporation of experimental and modeling approaches are recognized as important in future investigations. 


\section{AKNOWLEDGMENTS}

We are grateful to M. Lázaro (Sección Etología), D. Conde (Sección Limnología), D. Vizziano and A. Acuña (Sección Oceanología) from Facultad de Ciencias for their helpful comments on an early draft of the manuscript. We also thank the suggestions made by anonymous reviewers.

\section{REFERENCES}

AbDala, J.J. 1981. Asentamiento de larvas y crecimiento del mejillón Mytilus edulis platensis (d'Orbigny 1864) en la Bahía de Maldonado (Uruguay). Bachellor Thesis. Facultad de Humanidades y Ciencias. Universidad de la República. Uruguay. 40pp.

Abella, A., G. Arena, H. Nión \& C. Ríos. 1979. Peces bentónicos del Río de la Plata y de la Zona Común de Pesca Argentino-Uruguaya: 291-324. In: Memorias del Seminario sobre Ecología Bentónica y Sedimentación de la Plataforma Continental del Atlántico Sur (Montevideo - Uruguay, 9-12 de mayo de 1978). UNESCO, Montevideo.

Abreu, P.C., H.W. Graneli \& C. Odebrecht. 1995. Produção fitoplanctonica e bacteriana na regiao da pluma estuarina da Lagoa dos Patos, RS, Brasil. Atlântica (RS, Brazil) 17: 35-52.

Acuña, A., J. Verocai \& S. Márquez. 1992. Aspectos biológicos de Micropogonias furnieri (Desmarest 1823). Durante dos zafras en una pesquería artesanal al Oeste de Montevideo. Rev. de Biol. Mar., Valparaíso: 113 - 132.

Acuña, A. \& F. Viana. 2001. Ciclo reproductivo y características ambientales del área de desove de la pescadilla de red (Macrodon ancylodon) y la pescadilla de calada (Cynoscion guatucupa) en la costa uruguaya: 71-84. In: Vizziano D., P. Puig, C. Mesones \& G. Nagy (Eds.) El Río de la Plata. Investigación para la gestión del ambiente, los recursos pesqueros y la pesquería en el frente salino.

Acuña, A., F. Viana, D. Vizziano \& E. Danulat. 2000. Reproductive cycle of female Brazilian cosling, Urophysis brasiliensis (Kaup 1858) caught off the Uruguayan coast. Journal of Applied Ichthyology 16: 48-55.

Acuña, A., G. Arena, N. Berois, G. Mantero, A. Masello, H. Nión, S. Retta \& M. Rodríguez. 1997. The croacker (Micropogonias furnieri): biological cycle and fisheries in the Río de la Plata and its oceanic front: 191-228. In: Well P.G. \& G.R. Daborn (Eds.) The Río de la Plata, An environmental overview.

Akselman, R. 1985. Contribución al estudio de la Familia Gymnodiniceae Lemmermann (Dinophyta) del Atlántico Sudoccidental. Physis (Argentina) 43 (104): 39-50.
Alheit, J., J. de Ciechomski, L. DJurfeldt, C. Ebel, M.D. Ehrlich, J.C. Elgue, G. Mantero, Y. Matsuura, H. Mianzan, W. Nellen, C. Odebrecht, F. RAMÍREZ, R. SÁNCHEZ, G. SCHAFFER \& M.D. VIÑAS. 1991. SARP studies on Southwest Atlantic anchovy, Engraulis anchoita, off Argentina, Uruguay and Brazil. ICES, CM/L: 46, $30 \mathrm{pp}$.

AlLEN, J.A. \& H.L. SANDERS. 1997. The zoogeography, diversity and origin of the deep-sea protobranch bivalves of the Atlantic: the epilogue. Progress in Oceanography 38: 95-153.

Amaral W.J.A., M. Montú \& I.M. Gloeden. 1997. Salpidae (Thaliacea) da plataforma continental do extremo Sul do Brasil: Composição e abundância (Verâo de 1990). Atlântica (RS, Brazil), 19: 51-66

Amaro, J.A. 1965. La familia Mytilidae en el Uruguay. Revista del Instituto de Investigaciones Pesqueras (Uruguay), 1: 323-339.

Amaro, J. 1979. Mytilus edulis platensis-Pinnotheres maculatus, un caso de comensalismo con incidencia en la tecnología de las conservas de mariscos. Memorias del Seminario sobre Ecología Bentónica y Sedimentación de la Plataforma Continental del Atlántico Sur, UNESCO ORCYT 1: 273-278.

Angelescu, V. \& B. Prensky. 1987. Ecología trófica de la merluza común del Mar Argentino. (Merluccidae, Merluccius hubbsi). Parte 2. Dinámica de la alimentación analizada sobre la base de las condiciones ambientales, la estructura y las evaluaciones de los efectivos en su área de distribución. INIDEP, Mar del Plata, Argentina. Contribución No 561, $205 \mathrm{pp}$.

Arena, G., \& E. Hertl. 1983. Aspectos referentes al ciclo reproductor de la corvina blanca (Micropogon opercularis) de la subárea platense. Una primera evaluación de las informaciones disponibles desde 1976 a 1979. INAPE, Informe Técnico No 36. Montevideo, Uruguay. 26 pp.

Arena, G., C. García \& C. Silvera. 1974. La pesquería del tiburón con palangre desde el puerto de La Paloma. CARPAS/6/74, Informe Técnico 11.16 pp.

Arena, G., W. Ubal, P. Grunwaldt \& A .Fernández. 1986. Distribución latitudinal y batimétrica de la merluza (Merluccius hubbsi) y otros organismos demersales de su fauna acompañante, dentro de la zona común de pesca argentino - uruguaya. Publicaciones Comisión Técnica Mixta Frente Marítimo (Uruguay), 1(2): 253 - 280.

Arena, G., L. Barea, G. Beathyate, Y. Marín, C. Barreiro, D. BARREIRo \& J. Chocca. 1993. Experiencias de pesca de lenguado (Paralichtys spp.) con redes gemelas de baja apertura vertical. Informe Técnico, Instituto Nacional de Pesca (42): 93 pp. Montevideo.

Arena, G., V. Scarabino, O. Defeo, L. Barea, A. Masello, C. Layerle, F. Niggemeyer, G. Riestra \& G. Mantero. 1989a. Programa de investigación del mejillón Mytilus edulis platensis en las costas del Depto. de Maldonado, Uruguay. $1^{\text {er }}$ Informe 
Semestral (febrero- agosto 1988). Proyecto URU/ 87/008. PNUD-INAPE. 110 pp.

Arena, G., V. Scarabino, O. Defeo, L. Barea, A. Masello, C. Layerle, F. Niggemeyer, G. Riestra \& G. Mantero. 1989b. Programa de investigación del mejillón Mytilus edulis platensis en las costas del Depto. de Maldonado, Uruguay. ${ }^{\text {er }}$ Informe Anual (marzo 1988-febrero 1989). $2^{\circ}$ Informe Semestral (septiembre 1988-febrero 1989). Proyecto URU/ 87/008. PNUD-INAPE. 168 pp.

Arocena, R. 2000. Efectos de la eutrofización en el zoobentos de un sistema lacunar costero (L. Rocha, Uruguay) estudiados mediante mesocosmos. PhD Thesis Dissertation, Facultad de Ciencias Naturales y Museo Universidad Nacional de La Plata, Argentina. 135pp.

Arreguín, F., J.A. Sánchez \& O. Defeo. 1991. Análisis del crecimiento de la almeja amarilla (Mesodesma mactroides) de la costa uruguaya en base a datos de composición por longitudes. Frente Marítimo (Uruguay), 9: 75-81.

BACCINO, R.G. DE 1984. Estudio de una comunidad de almeja amarilla (Mesodesma mactroides Deshayes 1854) en la Playa Portezuelo, Depto. de Maldonado, Uruguay. Comunicaciones de la Sociedad Malacológica del Uruguay (Uruguay), 6 (46): 193-196.

BAKUn, A. \& R.H. PARrish. 1991. Comparative studies of coastal pelagic fish reproductive habitats: the anchovy (Engraulis anchoita) of the southwestern Atlantic. ICES Journal of Marine Science 48: 343361.

BALECh, E. \& S. Souto. 1980a. Los tintínidos de la campaña "Productividad IV". Parte I. Physis, 39(96): 18.

BALECH, E. \& S. Souto. 1980b. Los tintínidos de la campaña "Productividad IV". Parte II. Physis, 39(97): 41-49.

BATALlÉs M.L. 1983. La comunidad del mejillón Mytilus edulis platensis de Punta el Chileno: distribución, composición y estructura de la población. Bachellor Thesis. Facultad de Humanidades y Ciencias. Universidad de la República. Uruguay. $73 \mathrm{pp}$.

Batallés, L.M. \& V. García. 1984. Influencias de las salinidades entre 0 y 25 PPM en la sobrevivencia de Mytilus edulis platensis (Mollusca Bivalvia). Contribuciones del Depto. de Oceanografía de la Facultad de Humanidades y Ciencias (Uruguay), 1: $1-8$.

Batallés, L.M., V. García \& A. Malek. 1985. Observaciones sobre la zonación en el litoral rocoso de la costa uruguaya. I. Reconocimiento de los niveles superiores del sistema litoral: Cabo Polonio (Depto. de Rocha, Uruguay). Contribuciones del Depto. de Oceanografía de la Facultad de Humanidades y Ciencias (Uruguay), 2 (2): 42-50.

Batallés, M., O. Pin \& M. Lima. 1990. Estudio del crecimiento del lobo fino sudamericano (Arctocephalus australis) en Isla de Lobos, Uruguay.
Frente Marítimo (Uruguay) 7: 69-73.

Bazigaluz, A. 1981. Estudio sinóptico de parámetros hidrológicos y planctónicos de la costa de Montevideo, entre Punta Brava y Punta del Buceo en un mes de invierno. Bachellor Thesis, Facultad de Humanidades y Ciencias, Universidad de la República, Uruguay. $20 \mathrm{pp}$.

Bellisio, N.B., R.B. López \& A. Torno. 1979. Peces marinos patagónicos. Ministerio de Economía, SEIM. Subsecretaría de Pesca. Argentina. 279pp.

BERG, C. 1895. Enumeración sistemática y sinonímica de los peces de las costas argentina y uruguaya. Anales Museo Nacional Buenos Aires (Argentina) Serie II, 4(1): 1-120.

Berocay, O. 1983. Algunos aspectos de la biología del mejillón Mytilus edulis platensis de Punta el Chileno. Bachellor Thesis. Facultad de Humanidades y Ciencias. Universidad de la República. Uruguay. $73 \mathrm{pp}$.

Bianchi, A.A., C.F. Giulivi \& A. Piola. 1993. Mixing in the Brazil-Malvinas Confluence. Deep Sea Research, 40: 1345-1358.

BIER, R. 1985. Estudio de la macrofauna bentónica del curso inferior del arroyo Solís Grande (Canelones-Maldonado, Uruguay). Bachelor Thesis, Facultad de Humanidades y Ciencias, Universidad de la República, Uruguay. 140 pp.

Bisbal, G.A. 1995. The southeast South American large marine ecosystem. Marine Policy, 19: 21-38.

Blanco, A.C. 1989. Balance de masa de los nutrientes en la superficie del Río de la Plata y su area de influencia en el mar epicontinental uruguayo. Bachellor Thesis, Universidad de la República, Uruguay. $102 \mathrm{pp}$.

Boltovskoy, D. 1973. Los Eutecosomados del mar argentino y adyacencias (Mollusca, Pterópoda). Physis 32(85): 395-411.

Boltovskoy, D., M.J. Gibbons, L. Hutchings \& D. Binet. 1999. General biological features of the South Atlantic: 1-42. In: Boltovskoy D. (Ed.). South Atlantic zooplankton Backhuys publishers, Leiden.

Bonecker, A.C.T. \& G. Hubold. 1990. Distribution and abundance of larval gonostomatid fishes in the south west Atlantic. Meeresforschung, 33: 3851.

Brandhorst, W., J.P. Castello, R. Pérez Habiaga \& B.H. RoA. 1971a. Evaluación de los recursos de anchoíta (Engraulis anchoita) frente a la Argentina y Uruguay. III. Abundancia relativa entre las latitudes $34^{\circ} 40^{\prime} \mathrm{S}$ y $42^{\circ} 10^{\prime} \mathrm{S}$ en relación a las condiciones ambientales en mayo - junio de 1970. Instituto Biología Marina, Mar del Plata, Argentina; Serie Contribuciones $182,39 \mathrm{pp}$.

Brandhorst, W, J.P. Castello, .R Pérez Habiaga \& B.H. RoA. 1971b. Evaluación de los recursos de anchoíta (Engraulis anchoita) frente a la Argentina y Uruguay. V. Abundancia relativa entre las latitudes $34^{\circ} 30^{\prime} \mathrm{S}$ y $44^{\circ} 10^{\prime} \mathrm{S}$ en relación a las condiciones ambientales en agosto - setiembre de 1970. Insti- 
tuto Biología Marina, Mar del Plata, Argentina; Serie Contribuciones 183, 39 pp.

Brandohorst, W., J.P. Castello, R. Pérez Habiaga \& B.H. RoA. 1971c. Evaluación de los recursos de anchoíta (Engraulis anchoita) frente a la Argentina y Uruguay. V. Abundancia relativa entre las latitudes $34^{\circ} 30^{\prime} \mathrm{S}$ y $42^{\circ} 00^{\prime} \mathrm{S}$ en relación a las condiciones ambientales en octubre - noviembre de 1970. Instituto Biología Marina, Mar del Plata, Argentina; Serie Contribuciones, 184, 39 pp.

BrazeIro, A. 2000. Biodiversidad en hábitats costeros: playas y puntas rocosas de Uruguay: 127-141. In: Perfil ambiental del Uruguay/2000. Do-mínguez A. \& Prieto R.G. (Eds.) Editorial Nordan-Comunidad, Montevideo, Uruguay).

Brazeiro, A. \& O. Defeo. 1996. Macroinfauna zonation in microtidal sandy beaches: is it possible to identify patterns in such variable environments? Estuarine Coastal and Shelf Science, 42: 523-536.

Brazeiro, A. \& O. Defeo. 1999. Effects of harvesting and density-dependence on the demography of sandy beach populations: the yellow clam Mesodesma mactroides of Uruguay. Marine Ecology Progress Series, 182: 127-135.

Brazeiro, A., S. Méndez \& G. Ferrari. 1997. The first toxic bloom of Alexandrium tamarense in Uruguay: associated environmental factors. Atlântica (RS, Brazil), 19: 19-29.

CACHES, M.A. 1980. Nota sobre la biología de los depósitos fangosos circalitorales frente a Punta del Este, Uruguay. Boletim do Instituto Oceanográfico (SP, Brazil), 29 (2): 73-74.

Calliari, D., G. Cervetto, D. Bastreri, M. Gómez. 2001. Short-term variability in abundance and vertical distribution of the opposum shrimp Neomysis americana in the Solís Grande river estuary, Uruguay. Atlântica (RS, Brazil), 23: 117-125.

Cardezo, M.J. 1989. Caracterización de la fauna macrobentónica de la laguna de Rocha (Uruguay). Bachellor Thesis, Facultad de Humanidades y Ciencias, Universidad de la República, Uruguay. $95 \mathrm{pp}$.

Carreto, J.I., R. M. Negri \& H.R. Benavídez. 1986. Algunas características del florecimiento del fitoplancton en el frente del Río de la Plata. Revista Investigaciones Desarrollo Pesquero (Argentina), 5: 7-29.

Castello, J.P. \& O.O. Müller. 1977. On the oceanographic conditions in the Río Grande do Sul state. Atlântica (RS, Brazil), 2: 25-110.

Castilla, J.C. \& O. Defeo. 2001. Latin-American benthic shellfisheries: emphasis on co-management and experimental practices. Reviews in Fish Biology and Fisheries, 11: 1-30.

Cervetto, G. 1987. Fluctuaciones del zooplancton del Arroyo Solís Grande, Uruguay (16 al 30/11/82). Bachellor Thesis, Facultad de Humanidades y Ciencias, Universidad de la República, Uruguay, $154 \mathrm{pp}$.

Cervetto, G., C. Mesones \& D. Calliari. 2002.
Phytoplankton biomass and its relation to environmental variables in a disturbed coastal area of the Río de la Plata, Uruguay. Atlântica (RS, Brazil) 24(1): 45-54.

Charmantier, G., L. Giménez, M. Charmantier-Daures \& K. ANGER. 2002. Ontogeny of osmoregulation, physiological plasticity, and export strategy in the grapsid crab Chasmagnathus granulata (Crustacea, Decapoda). Marine Ecology Progress Series, 229: 185-194.

Christiansen, H.E., P.D. Glorioso \& C.E. Olivieri. 1986. Aplicación de la histología en la determinación de los efectivos de merluza (Merluccius hubbsi). Tipificación de tejidos, cálculos de fecundidad y vinculación con las condiciones ambientales. $\mathrm{Pu}-$ blicaciones Comisión Técnica Mixta Frente Marítimo (Uruguay), 1(2): 567 - 574.

Ciechomski, J. DE \& G. Weiss. 1974. Distribución de huevos y larvas de merluza, Merluccius hubbsi, en las aguas de la plataforma de la Argentina y Uruguay en relación con la anchoita, Engraulis anchoíta, y las condiciones ambientales. Physis 33: 185 - 198.

Ciechomski, J.D. \& R. Sánchez. 1986. Problemática del estudio de huevos y larvas de anchoita (Engraulis anchoita) en relación con la evaluación de sus efectivos pesqueros. Reseña de veinte años de investigación. Publicaciones Comisión Técnico Mixta Frente Marítimo (Uruguay), 1: 93-96.

Ciechomsky, J.D. DE, M.D. Ehrlich, C.A. Lasta \& R.P. SANCHEZ. 1979. Campañas realizadas por el buque de investigación "Walther Herwing” en el Mar Argentino, desde mayo hasta noviembre de 1978. Organización y reseña de datos básicos obtenidos. INIDEP, Mar del Plata, Argentina. Contribución $\mathrm{N}^{\mathrm{o}} 374 ; 311$ pp.

Ciotti, C.M., C. Odebrecht, G. Fillmann \& O.O. Moller JR. 1995. Freshwater outflow and Subtropical Convergence influence on phytoplankton biomass in the southern brasilian continental shelf . Continental Shelf Research, 15(14):1737-1756.

Coll, J. 1979. Catálogo de Algas citadas para Uruguay. SOHMA. Uruguay, 133pp.

Conde D. 2001. Influencia del régimen hidrológico y de la radiación solar ultravioleta en la producción de comunidades microalgales en una laguna costera del Atlántico Sur. PhD Thesis Dissertation PEDECIBA, Universidad de la República, Uruguay.

Conde, D., L. Aubríot, S. Bonilla \& R. Sommaruga. 2002. Marine intrusions in a coastal lagoon enhance the negative effect of solar U.V. radiation on phytoplankton photosynthetic rates. Marine Ecology Progress Series, 207: 19-31.

Conde, D., S. Bonilla, L. Aubriot, R. de León \& W. Pintos. 1999. Comparison of the areal amount of chlorophyll a of planktonic and attached microalgae in a shallow coastal lagoon. Hydrobiologia, 408/409: 285-291.

Corbellini, L. 1983. Contribución al conocimiento de la fauna bentónica de la Laguna de Rocha (ROU). 
Bachellor Thesis, Facultad de Humanidades y Ciencias, Universidad de la República, Uruguay. $111 \mathrm{pp}$.

Cousseau, B. 1985. Los peces del Río de la Plata y su frente marítimo: 515-534. In: Yáñez-Arancibia (Ed.) Ecología de comunidades de peces en estuarios y lagunas costeras: hacia una integración de ecosistemas. Universidad Nacional Autónoma, México.

Cousseau, M.B., J.E. Hansen \& D.L. Gru. 1979. Campañas realizadas por el buque de investigación "Shinkai Maru" en el Mar Argentino, desde abril de 1978 hasta abril de 1979. Organización y reseña de datos básicos obtenidos. INIDEP, Mar del Plata, Argentina. Contribucion No 373; 625 pp.

Cousseau, M.B., C. Cortina, H. Cordo \& G. Burgos. 1986. Análisis de datos biológicos de corvina rubia (Micropogonias furnieri) y pescadilla de red (Cynoscion striatus) obtenidos en dos campañas del año 1983. Publicaciones de la Comisión Técnica Mixta del Frente Marítimo (Uruguay), 1: 319-332.

Cousseau, B., H. Nión, M.A. Denegri \& S. Olivera. 1998. Lista de peces de la Zona Común de Pesca Argentino-Uruguaya. Frente Marítimo (Uruguay), 17: $123-154$

Danulat, E., P. Muñzz, J. García \& B. Yannicelli. 2002. First assessment of the highly contaminated harbour of Montevideo, Uruguay. Marine Biology, 44:554-565.

Day, J.W., C.A.S. Hall, W.M. Kemp \& A. YañezArancibia. 1989. Estuarine ecology. Wiley \& Sons publications. $558 \mathrm{pp}$.

De Alava, A. \& O. Defeo. 1991. Distributional pattern and population dynamics of Excirolana armata (Isopoda: Cirolanidae) in an Uruguayan sandy beach. Estuarine, Coastal and Shelf Science, 33: 433-444.

De Buen, F. 1950. El Mar de Solís y su fauna de peces (2a parte). Servicio Oceanográfico y Pesca del Uruguay (SOYP). Publicaciones Científicas, 2: 44-144.

De León, L. \& J.S. Yunes. 2001. First report of a Microcystin-Containing Bloom of the Cynobacterium Microcystis aeruginosa in the La Plata River, South America. Enviromental Toxicology 16(1): 110-112.

DefEo, O. 1985a. Aspectos biocenológicos y de dinámica de población de "almeja amarilla" Mesodesma mactroides (Deshayes 1854) en la zona de la Barra del Chuy, Depto. de Rocha, Uruguay. I. Biocenología. Contribuciones Depto. Oceanografía, Facultad de Humanidades y Ciencias (Uruguay), 2(3): 50-75.

DEFEo, O. 1985b. Aspectos biocenológicos y de dinámica de población de "almeja amarilla" Mesodesma mactroides (Deshayes 1854) en la zona de la Barra del Chuy, Depto. de Rocha Uruguay. II. Dinámica de la población. Contribuciones Depto. Oceanografía, Facultad de Humanidades y Ciencias
(Uruguay), 2(4): 76-98.

Defeo, O. 1987. Consideraciones sobre la ordenación de una pesquería en pequeña escala. Biología Pesquera (Chile), 16: 47-62.

Defeo, O. 1989a. Development and management of artisanal fishery for yellow clam Mesodesma mactroides in Uruguay. Fishbyte, 7(3): 21-25.

Defeo, O. 1989b. Hacia un manejo y desarrollo integral de pesquerías artesanales: la almeja amarilla Mesodesma mactroides, de la costa atlántica uruguaya: 244-252. In: Arrizaga, A. (Ed.), Pesca Artesanal, hacia un desarrollo costero integrado. Memorias del II Seminario Latinoamericano de Pesca Artesanal (Talcahuano, Chile).

Defeo, O. 1993. Repopulation of coastal invertebrates through the management of natural areas: a successful example. Out of the Shell, 3(2): 11-13.

Defeo, O. 1996a. Experimental management of an exploited sandy beach bivalve population. Revista Chilena de Historia Natural, 69: 605-614.

Defeo, O. 1996b. Recruitment variability in sandy beach macroinfauna: much to learn yet. Revista Chilena de Historia Natural, 69: 615-630.

Defeo, O. 1998. Testing hypotheses on recruitment, growth and mortality in exploited bivalves: an experimental perspective. Canadian Journal of Fisheries and Aquatic Sciences, Special Publication 125: 257-264. ISBN: 0-660-17221-6.

Defeo, O. 2003. Marine invertebrate fisheries in sandy beaches: an overview. Journal of Coastal Research, 35: pp. 56-65.

Defeo, O. \& V. ScARABINO. 1990. Ecological significance of a possible deposit-feeding strategy in Mesodesma mactroides (Deshayes, 1854) (Mollusca: Pelecypoda). Atlântica (RS, Brazil) 12(1): 55-66.

Defeo, O. \& A. Brazeiro. 1994. Distribución, estructura poblacional y relaciones biométricas de la vieira Zygochlamys patagonica en aguas uruguayas. Comunicaciones de la Sociedad Malacológica del Uruguay, 7 (66-67): 362-367.

Defeo, O. \& A. De Alava. 1995. Effects of human activities on long-term trends in sandy beach populations: the wedge clam Donax hanleyanus in Uruguay. Marine Ecology Progress Series, 123: 73-82.

Defeo, O. \& A. Masello. 2000a. La pesquería de cangrejo rojo Chaceon notialis en el Uruguay: un enfoque de manejo precautorio (1995 y 1996): 7-22. In: Rey, M. (Ed.). Recursos pesqueros no tradicionales: moluscos, crustáceos y peces bentónicos marinos. Proyecto URU/92/003. INAPE-PNUD.

Defeo, O. \& A. Masello. 2000b. Análisis espacio-temporal de la pesquería de cangrejo rojo Chaceon notialis en el Uruguay: año 1996: 23-37. In: Rey M (Ed.). Recursos pesqueros no tradicionales: moluscos, crustáceos y peces bentónicos marinos. Proyecto URU/92/003. INAPE-PNUD.

Defeo, O. \& N. Gutiérrez. 2000. Pautas biológico- 
pesqueras para el desarrollo de la pesquería de vieira Zygochlamys patagonica en aguas uruguayas: distribución, estructura poblacional y relaciones biométricas: 39-45. In: Rey M. (Ed.). Recursos pesqueros no tradicionales: moluscos, crustáceos y peces bentónicos marinos. Proyecto URU/92/003. INAPE-PNUD.

Defeo, O. \& D. LeRcari. 2000. Impacto ecológico en la costa. Efectos del Canal Andreoni sobre playas de Rocha. Posdata (Uruguay), (295): 68-70.

Defeo, O. \& M. Rueda. 2002. Spatial structure, sampling design and abundance estimates in sandy beach macroinfauna: some warnings and new perspectives. Marine Biology, 140: 12151225.

Defeo, O. \& A. DE Alava. 2002. Impacto humano en la biodiversidad de playas arenosas. Un estudio de caso. In: Moreno-Casasola P., M.L. Martínez \& O. Defeo (Eds.): Manejo de zonas costeras y su impacto en la biodiversidad: estudios de caso. Red Iberoamericana de Biodiversidad de Ecosistemas Costeros CYTED-Instituto de Ecología, Xalapa, Veracruz: 239. pp. 169-179.

Defeo, O. \& R.S. Cardoso. 2002. Macroecology of population dynamics and life history traits of the mole crab Emerita brasiliensis in Atlantic sandy beaches of South America. Marine Ecology Progress Series: in press.

Defeo, O., C. Layerle \& A. Masello. 1986. Spatial and temporal structure of the yellow clam Mesodesma mactroides (Deshayes, 1854) in Uruguay. Medio Ambiente (Chile), 8(1): 4857.

Defeo O., A. Masello \& C. Layerle. 1988. Consideraciones metodológicas para el estudio del crecimiento en moluscos bivalvos. Informes Unesco en Ciencias del Mar, 47: 135-148.

Defeo, O., J.C. Seijo, J. Euan \& M. Liceaga. 1991a. Dinámica espacial del esfuerzo pesquero en una pesquería artesanal de la costa atlántica uruguaya. Investigaciones Pesqueras (Chile), 36: 17-25.

Defeo, O., V. Little \& L. Barea. 1991b. Stock assessment of the deep-sea red crab Chaceon notialis in the Argentinian-Uruguayan Common Fishing Zone. Fisheries Research, 11: 25-39.

Defeo, O., E. Jaramillo \& A. Lyonnet. 1992A. Community structure and intertidal zonation of the macroinfauna in the Atlantic coast of Uruguay. Journal of Coastal Research, 8: 830-839.

Defeo O., E. Ortiz \& J.C. Castilla. 1992в. Growth, mortality and recruitment of the yellow clam Mesodesma mactroides in Uruguayan beaches. Marine Biology, 114: 429-437.

Defeo, O., F. Arreguin-SÁnchez \& J.A. Sánchez. 1992C. Growth study of the yellow clam Mesodesma mactroides: a comparative analysis of the application of three length-based methods. Scientia Marina, 56: 53-59.

Defeo, O., A. Brazeiro \& G. Riestra. 1996. Impacto de la descarga de un canal artificial en la biodiversidad de gasterópodos en una playa de arena de la costa atlántica uruguaya. Comunicaciones de la Sociedad Malacológica del Uruguay, 8(70-71): 13-18.

Defeo, O., J. Gómez \& D. Lercari. 2001. Testing the swash exclusion hypothesis in sandy beach populations: the mole crab Emerita brasiliensis in Uruguay. Marine Ecology Progress Series, 212: 159-170.

Defeo, O., J. Gómez \& D. Lercari. 2003. The role of morphodynamics in structuring sandy beach populations and communities: what should be expected? Journal of Coastal Research, 35: 352362.

Defeo, O., L. Barea, F. Niggemeyer \& V. Little. 1989. Abundancia, distribución y dimensionamiento de la pesquería de cangrejo rojo Geryon quinquedens Smith, 1879 en el Atlántico Sudoccidental. Informe Técnico INAPE $\mathrm{N}^{\circ} 38$ : $72 \mathrm{pp}$.

Defeo, O., A. de Alava, V. Valdivieso \& J.C. Castilla. 1993. Historical landings and management options for the genus Mesodesma in coasts of South America. Biología Pesquera (Chile), 22: 4154.

Defeo, O., A. Brazeiro, A. de Alava \& G. Riestra. 1997. Is sandy beach macroinfauna only physically controlled? Role of substrate and competition in isopods. Estuarine, Coastal and Shelf Science, 45: 453-462.

Demichelli, M.A. 1984. Estudios exploratorios del infralitoral de las playas arenosas uruguayas. I. Playa Portezuelo. Comunicaciones de la Sociedad Malacológica del Uruguay (Uruguay), 6(47): 235-241, 4 mapas.

Demichelli, M.A. 1985a. Estudios exploratorios del infralitoral de las playas arenosas uruguayas: II. Datos complementarios sobre Playa Portezuelo. Comunicaciones de la Sociedad Malacológica del Uruguay (Uruguay), 6 (48): 287-290, 1 mapa.

Demichelli, M.A. 1985b. Estudios exploratorios del infralitoral de las playas arenosas uruguayas: III, Playa Anaconda. Comunicaciones de la Sociedad Malacológica del Uruguay (Uruguay), 6 (49): 301-309, 3 mapas.

Devincenzi, G. 1920a. Peces del Uruguay. Anales del Museo de Historia Natural de Montevideo (Uruguay) 1, Ser. 2, 4: 99-134, Láminas IX a XII.

DevincenzI, G. 1920b. Notas ictiológicas I. El género Symphurus en el Río de la Plata. Anales del Museo de Historia Natural de Montevideo, (Uruguay) 1, Ser. 2, 4: 135-138.

Devincenzi, G. 1924. Peces del Uruguay. Anales del Museo de Historia Natural de Montevideo (Uruguay) 1, Serie 2, 5: 139-293, Láminas I a XXIV.

DevincenzI, G. 1933. Peces del Uruguay. Notas complementarias II. Anales del Museo de Historia Natural de Montevideo (Uruguay), 1, Serie 2, 4(13): 1-11, 1 lámina. 
DevincenZi, G. 1939a. Peces del Uruguay. Notas complementarias III. Anales del Museo de Historia Natural de Montevideo, Serie 2, 4(13): 1-38.

DevincenZI, G. 1939b. Notas ictiológicas sobre peces de la región patagónica. Anales del Museo de Historia Natural de Montevideo (Uruguay), Serie 2, 4(14): 1-21.

Devincenzi, G. \& L.P. Barattini. 1926. Album ictiológico del Uruguay. Anales del Museo de Historia Natural de Montevideo (Uruguay), Serie 1: 1-15, 51 figuras.

Devincenzi, G. \& L.P. Barattini. 1928. Album ictiológico del Uruguay. Anales del Museo de Historia Natural de Montevideo (Uruguay), Serie 2, tomo 2, entrega 4, láminas XIII-XXIV.

Devincenzi, G. \& D. Legrand. 1936. Album ictiológico del Uruguay. Anales del Museo de Historia Natural de Montevideo (Uruguay), Serie 3, láminas XXV-XXXVI.

Devincenzi, G. \& D. Legrand. 1940. Album ictiológico del Uruguay. Anales del Museo de Historia Natural de Montevideo (Uruguay), suplemento, láminas XXXVI-LII.

Díaz de Astarloa, J.M., A. Aubone \& M.B. Cousseau. 1999. Asociaciones ícticas de la plataforma costera de Uruguay y norte de Argentina, y su relación con los parámetros ambientales. Physis 57(132-133): 29-45.

Domingo, A. 2000. Elasmobranquios pelágicos capturados por la flota de long-line uruguaya: 1526. In: Rey M. (Ed.) Consideraciones sobre la pesca incidental producida por la actividad de la flota atunera dirigida a grandes pelágicos. INAPE- PNUD URU/92/003.

Domingo, A., O. Mora \& A. Milessi. 1996. Captura de tiburones pelágicos desembarcados por la flota atunera de Uruguay. Colección Documentos Científicos XLVI (4) ICCAT SCRS/96/ 42: 420-424.

Domingo, A., O. Mora \& M. Cornes. 2002. Evolución de las capturas de elasmobranquios pelágicos en la pesquería de atunes de Uruguay, con énfasis en los tiburones azul (Prionace glauca), moro (Isurus oxhyrinchus) y porbeagle (Lamna nasus). Colección Documentos Científicos LIV (4) ICCAT SCRS/96/42: 1406-1420.

Ehrhardt, N., G. Arena, A. Abella, Z. Varela, E. Sánchez, C. Ríos \& N.B. de Moratorio. 1977a. Evaluación preliminar de los recursos demersales en la Zona Común de Pesca Argentino - Uruguaya. INAPE, Montevideo, Uruguay. Informe Técnico 11: $176 \mathrm{pp}$.

Ehrhardt, N., H. Nión, H. Castaldo \& L. Barea. 1977b. Evaluación preliminar de los recursos pelágicos del area común de pesca Argentino-Uruguaya. INAPE, Montevideo, Documento Técnico Nº14, $79 \mathrm{pp}$.

Ehrhardt, N., G. Arena, A. Abella, C. Ríos, N.B. De Moratorio \& M. Rey. 1979. Evaluación preliminar de los recursos demersales en la Zona
Común de Pesca Argentino - Uruguaya. INAPE, Montevideo, Uruguay. Informe Técnico $\mathrm{N}^{\circ} 13,186 \mathrm{pp}$.

Ehrlich, M. 2000. Distribución y abundancia de huevos, larvas y juveniles de merluza (Merluccius hubbsi) en la Zona Común de Pesca ArgentinoUruguaya, 1996-1998. Frente Marítimo (Uruguay), 18: 31-44.

Ehrlich, M. \& J. Ciechomski. 1994. Reseña sobre la distribución de huevos y larvas de merluza (Merluccius hubbsi) basada en veinte años de investigaciones. Frente Marítimo (Uruguay), 15: 37-50.

Elgue, J.C. \& M. Faget. 1986. Aplicación de índices de similitud a un inventario de poliquetos bentónicos de la costa oceánica del Uruguay. $13^{\text {a }}$ Reunión Argentina de Ecología, Bahía Blanca, Argentina, Resumen 55.

Elgue, J.C., M. Alamón \& O. Labuonora. 1987. Una descripción de la Zona Común de Pesca ArgentinoUruguaya mediante el análisis en componentes principales de parámetros ambientales y datos de fitoplancton para el invierno de 1983. Publicaciones Comisión Técnico Mixta Frente Marítimo (Uruguay), 3: 15-23.

Elgue, J.C., C. Bayssé, F. Burone \& M. Parietti. 1990. Distribución y sucesión espacial del fitoplancton de superficie de la Zona Común de Pesca Argentino-Uruguaya (invierno de 1983). Publicaciones Comisión Técnico Mixta Frente Marítimo (Uruguay), 6: 67-107.

Errea, A., G. Mantero, A. Martínez, G. Martínez, C. Mesones, L. Ortega \& R. Vogler. 1999. Estudio comparativo de la distribución y abundancia de juveniles de merluza (Merluccius hubbsi) en la zona común de pesca Argentino - Uruguaya: 153-163. In: Rey, M. \& G. Arena (Eds.) Merluza. Estudios realizados dentro de la Zona Común de Pesca Argentino-Uruguaya en el marco del Plan de Investigación Pesquera URU/92/003. ISBN: 9974-563-02-X.

Escofet, A., N. Gianuca, S. Maytía \& V. Scarabino. 1979. Playas arenosas del Atlántico Sudoccidental entre $\operatorname{los} 29^{\circ}$ y $43^{\circ} \mathrm{S}$ : consideraciones generales y esquema biocenológico. Memorias del Seminario sobre Ecología Bentónica y Sedimentación de la Plataforma Continental del Atlántico Sur, 1: 245-258. UNESCO Montevideo.

Esnal, G.B. 1970. Sobre la distribución de algunos tunicados, Familia Salpidae, en aguas frente a la Provincia de Buenos Aires. Physis, 30(80): 241249.

EsNAL, G.B. 1978. Características generales de la distribución de tunicados pelágicos del Atlántico Sudoccidental, con algunas observaciones morfológicas. Physis, 38(94): 91-102.

Fabiano, G., O. Santana, E. Delfino \& A. Riet. 2000a Análisis de la pesquería de lenguado Paralichtys patagonicus en La Paloma, Uruguay: 51-72. In: Rey, M. (Ed.) Recursos pesqueros no tradiciona- 
les: moluscos, crustáceos y peces bentónicos marinos. Proyecto URU/92/003. INAPE-PNUD.

Fabiano, G., G. Riestra, O. Santana, E. Delfino \& R. Fоті. 2000b. Consideraciones sobre la pesquería del caracol fino Zidona dufresnei (Mollusca, Gastropoda) en el Uruguay: período 1996-1997. In: Rey, M. (Ed.) Recursos pesqueros no tradicionales: moluscos bentónicos marinos. Proyecto URU/92/003: 114/142. INAPE-PNUD.

FERNÁNDEZ, A. \& W. NorBIS. 1986. Distribución y abundancia de la castañeta (Cheilodactylus bergi) en la Zona Común de Pesca Argentino-Uruguaya en el período 1980-1984. Publicaciones Comisión Técnica Mixta Frente Marítimo (Uruguay), 1(1): 180-190.

Fernández, N.C., B.A. SAntos \& F. Ramírez. 1994. Análisis ecológico de la distribución de los copépodos, de una campaña de primavera, en la Zona Común de Pesca. Frente Marítimo (Uruguay), 15: 133-140.

Framiñan, M.B. \& O.B. Brown. 1996. Study of the Río de la Plata turbidity front. Part I: Spatial and temporal distribution. Continental Shelf Research, 16:1259-1283.

GaLli, O. 1999. Análisis espacio-temporal de la alimentación de la merluza (Merluccius hubssi) en el frente oceánico del Río de la Plata: 70-83. In Rey, M. \& G. Arena (Eds.) Merluza. Estudios realizados dentro de la Zona Común de Pesca Argentino-Uruguaya en el marco del Plan de Investigación Pesquera URU/92/003. ISBN: 9974563-02-X.

Galli, O. \& W. Norbis. 1992. Presencia de juveniles de Cheilodactylus bergi (Pisces: Cheilodactylidae) en la Zona Común de Pesca Argentino-Uruguaya. Boletín de la Sociedad Zoológica del Uruguay (Uruguay) (2 $2^{\text {a }}$ Epoca), 7: 69 - 70.

GARCíA, C.A.E. 1997. Physical Oceanography: 94-96. In: Seeliger, U., C.O. Odebrecht \& J.P. Castello (Eds.) Subtropical convergence environments: the coast and sea in the Southwestern Atlantic.

García, F. \& A. WitKowsky. 2002. Inferring past sea-level variations from relative percentages of Pseudopodosira kosugi in Rocha lagoon, SE Uruguay. Diatom Research, in press.

García, F., C. Castiñeira, B. Scharf \& P. Sprechmann. 2002.The relationship between sea level and trophic state in Rocha lagoon, SE Uruguay. Neues Jahrbuch fuer Geologie und Palaeontologie Mh 2002: 27-47.

García, F., L. del Puerto, H. Inda, C. Castiñeira, R. Bracco, P. Sprechmann \& B.W. Scharf. 2001. Preliminary paleolimnological study of Rocha lagoon, SE Uruguay. Limnologica, 31: 221-228.

Garzoli, S.L. \& Z. GARRAFO. 1989. Transports, frontal motions and eddies at the Brazil-Malvinas Currents Confluence. Deep Sea Research, 36: 681703.

Gayoso, A.M. 1996. Phytoplankton species composition and abundance off the Río de la Plata (Uruguay).
Archive of Fisheries and Marine Research, 44: 257-265.

Gayoso, A.M. \& G.P. Podestá. 1996. Surface hydrography and phytoplankton of the Brazil-Malvinas currents confluence. Journal Plankton Research, 18(6): 941-951.

GIFFORD, D.J. \& M.J. DAGG. 1988. Feeding of the estuarine copepod Acartia tonsa Dana: carnivory vs herbivory in natural microplankton assemblages. Bulletin of Marine Science, 43(3): 458-468.

GiMÉnEz, L. 2000. El efecto de la salinidad y la biomasa inicial en el desarrollo larval del cangrejo estuarino Chasmagnathus granulata (Crustacea, Decapoda). PhD Thesis Dissertation, PEDECIBA, Universidad de la República, Uruguay.

GimÉNEZ, L. 2002. Effects of prehatching salinity and initial larval biomass on survival and duration of development in the zoea 1 of the estuarine crab Chasmagnathus granulata under nutritional stress. Journal Experimental Marine Biology and Ecology, 270: 93-110.

GIMÉNEZ, L. \& B. YANNICELLI. 1997. Variability of zonation patterns in temperate microtidal Uruguayan beaches with different morphodynamic types. Marine Ecology Progress Series, 160: 197-207.

GimÉnEZ, L. \& B. YANNICELLI. 2000. Longshore patterns of distribution of macroinfauna on a Uruguayan sandy beach: an analysis at different spatial scales and of their potential causes. Marine Ecology Progress Series, 199: 111-125.

GimÉnez, L. \& K. Anger. 2001. Relationships among salinity, egg size, embryonic development, and larval biomass in the estuarine crab Chasmagnathus granulata Dana, 1851. Journal Experimental Marine Biology and Ecology, 260, 241-257.

Gnasso, G., F. MaÑE-Garzón \& J. Leymonie. 1978. Estudios sobre la biología del cangrejo de estuario Chasmagnathus granulata Dana 1851 (IV). Ionograma normal en poblaciones de diferente salinidad. Revista de Biología Uruguaya (Uruguay), 4 (1): 5-17.

Goberna, E. 1986. Copépodos planctónicos del sector uruguayo de la Zona Común de Pesca Argentino-Uruguaya. Publicaciones Comisión Técnico Mixta Frente Marítimo (Uruguay), 1(2): 581-597.

Goberna, E. 1987. Estudio sobre contenido digestivo en diversas especies de juveniles de peces. Análisis comparativo. Publicaciones Comisión Técnica Mixta Frente Marítimo (Uruguay), 3: 93-101.

Goberna, E. 1988. Zooplancton de borde de plataforma II. Copépoda, composición especifica, taxocenosis. Publicaciones Comisión Técnico Mixta Frente Marítimo (Uruguay), 4: 143-150.

Gómez, M. 1987. Consideraciones sobre la Bioecología de la familia Pontellidae (Dana, 1852) (Copépoda, Calanoida) en la Zona Común de Pesca. Tesis de Licenciatura, Facultad de Humanidades y Ciencias, Universidad de la República, Uruguay. 145 pp.

Gómez, J. \& O. Defeo. 1999. Life history of the sand- 
hopper Pseudorchestoidea brasiliensis (Amphipoda) in sandy beaches with contrasting morphodynamics. Marine Ecology Progress Series, 182: 209-220.

Gómez, M., W. Norbis \& D. BASTRERI. 2000. Wind effect as forcing factor controlling distribution and diversity of copepods in a shallow temperate estuary (Solís Grande-Uruguay). Scientia Marina, 64(1): 87-95.

Gómez, M., J.J. Lagomarsino, K. NúÑEz, D. Vizziano \& G. NAGY. 2001. Producción fitoplanctónica en la región frontal del Río de la Plata. In: Vizziano, D., P. Puig, C. Mesones \& G. Nagy (Eds.) El Río de la Plata. Investigación para la gestión del ambiente, los recursos pesqueros y la pesquería en el frente salino: 33-45.

GonZÁLEZ, L.A. 1972. Hallazgo de Neomysis americana Smith (1873) (Crustacea-Mysidacea) en el Río de la Plata. Revista de Biología del Uruguay, 2(2): 119-130.

Gordon, J.L. 1989. Brazil-Malvinas Confluence. Deep Sea Research, 36: 359-384.

GrÜNDWALDT, P. 1986. Contribución al conocimiento de la fecundidad y el carácter del desove de la merluza (Merluccius hubbsi). Publicaciones Comisión Técnica Mixta Frente Marítimo (Uruguay), 1(1): 110 - 120.

Guerrero, R.A., E.M. Acha, M.B. Framiñan \& C.A. LASTA. 1997. Physical oceanography of the Río de la Plata Estuary, Argentina. Continental Shelf Research, 17 (7): 727-742.

Hazin, F., M.K. Broadhurst, A.F. Amorin, C.A. Arfelli \& A. Domingo. (in press). Catches of pelagic sharks by subsurface longline fisheries in the South Atlantic Ocean: a review of available data with emphasis on Uruguay and Brazil. In: Camhi, M. \& E. Pikitch (Eds.) Sharks of the open ocean. Blackwell Scientific, New York.

HoLmBerG, E.H. 1888. Nombres vulgares de peces argentinos y sus equivalentes científicos. La Educación, Buenos Aires: 361-378.

Hubold, G. 1980a. Hydrography and plankton off southern Brazil and Río de la Plata. Autumn cruice: April-June 1978. Atlântica (RS, Brasil) 4:23-42.

Hubold, G. 1980b. Second report on hydrography and plankton off Southern Brazil and Río de la Plata. August-November 1977. Atlântica (RS, Brazil) 4:2-22.

Hubold, G. \& M.D. Ehrlich. 1981. Distribution of eggs and larvae of five fish species in the south western Atlantic between $25^{\circ}$ and $40^{\circ}$. Meeresforschung, 29: 17-29.

Ishino, M., K. IWASAKi, K. Otsuka \& K. Kihara. 1983. Demersal fish community in relation to the abiotic environmental conditions in the waters off Argentina. Journal Tokio University Fisheries, 70 (1-2): 37- 58.

Jorcín, A. 1989. Aspectos ecológicos y biológicos de Erodona mactroides (Mollusca: Bivalvia, Daudin 1801). En la Laguna de Rocha, Uruguay. Bachellor
Thesis, Facultad de Humanidades y Ciencias, Universidad de la República. 101 pp.

Jorcín, A. 1993. Estudo da estrutura e funcionamento da comunidade macrozoobentonica do sistema laguna de Castillos-arroyo Valizas (Depto. de Rocha, Uruguay). MSc thesis, University of Sao Paulo, Brasil. 126 pp.

Jorcín, A. 1999. Temporal and spatial variability in the macrobenthic community along a salinity gradient in the Castillos lagoon (Uruguay). Archive für Hydrobiologie, 146: 369-384.

Juanicó, M. \& M. Rodríguez. 1976. Composición faunística de la comunidad de Mytilus edulis platensis d'Orbigny, 1846 ubicada a unas 55 millas al SE de La Paloma. Comunicaciones de la Sociedad Malacológica del Uruguay (Uruguay)4 (29): 113-116.

Kiorboe, T., Saiz E. 1995. Planktivorous feeding in calm and turbulent environments, with emphasis on copepods. Marine Ecology Progress Series, 122:135-145.

Lalli, C.M. \& T.R. Parsons. 1997. Biological Oceanography. An introducion. Butterworth Heinemann, Oxford. 314 pp.

Lange, C.B. \& E.L. Mostajo. 1985. Phytoplankton (Diatoms and Silicoflagellates) from the Southwestern Atlantic Ocean. Botánica Marina, 28: 469-476.

Layerle, C. \& V. Scarabino. 1984. Moluscos del frente marítimo uruguayo entre 9 y $78 \mathrm{~m}$ de profundidad: análisis biocenológico. Contribuciones del Depto. de Oceanografía, Facultad de Humanidades y Ciencias (Uruguay), 1 (9): 1-17.

LÁzARo, M. 2001. Estructura genética poblacional de la franciscana (Pontoporia blainvillei). MSc. Thesis. PEDECIBA, Universidad de la República, Uruguay. 93pp.

Little, V., L. Rodríguez \& M. Lázaro. 1997. Capturas incidentales de Pontoporia blainvillei en las pesquerías artesanales del Departamento de Rocha, Uruguay, durante 1992 y 1993: 70-77. In: Pinedo, M.C. \& A.S. Barreto (Eds.) Anais do segundo encontro sobre coordenaçao de manejo e pesquisa da franciscana.

LEGECKIS, R. \& A.L. GoRDON. 1982. Satellite observations of the Brazil and Falkland currents 1975 to 1976 and 1978. Deep Sea Research, 29: 375-402.

Lercari, D. \& O. DeFEo. 1999. Effects of freshwater discharge in sandy beach populations: the mole crab Emerita brasiliensis in Uruguay. Estuarine Coastal and Shelf Science, 49: 457-468.

LeRCARI, D. \& O. Defeo. 2003. Variation of a sandy beach macrobenthic community along a human-induced environmental gradient. Estuarine, Coastal and Shelf Science, 585: 17-24.

LETA, H.R. 1992. Contribución al conocimiento de la biología del pulpo (Vosseledone charrua) en aguas uruguayas. Frente Marítimo (Uruguay), 11: 9397.

LETA, H. 1987. Contribución al conocimiento de la alimen- 
tación de la pescadilla de red (Macrodon ancylodon). Publicaciones de la Comisión Técnica Mixta del Frente Marítimo (Uruguay), 3: 77-78.

LimA, M. 1998. Population persistence and extinction of the South America fur seal (Arctocephalus australis) at Uruguayan coasts. Estudios Oceanológicos, 17: 87-94.

LiMA, M. \& E. PAÉz. 1997. Demography and population dynamics of the South American fur seal. Journal of Mammalogy, 78 (3): 914-920.

Lima, M. \& E. PÁEz. 1995. Growth and reproductive patterns in the South American fur seal. Journal of Mammalogy, 76 (4): 1249-1255.

Lima, M., A. Brazeiro \& O. Defeo. 2000. Dynamics of a yellow clam (Mesodesma mactroides) population: recruitment variability, density-dependence and stochastic processes. Marine Ecology Progress Series, 207: 97-108.

Longhurst, A. 1998. Ecological geography of the sea. Academic Press, London. 389 pp.

LóPez, R.B. 1963. Problemas sobre la distribución geográfica de los peces marinos sudamericanos. Revista Museo Argentino Ciencias Naturales Bernardino Rivadavia (Argentina), 1(3): 109-135.

LóPEZ, R.B. 1964. Problemas de la distribución geográfica de los peces marinos sudamericanos. Boletín del Instituto de Biología Marina de Mar del Plata (Argentina), 7: 57-63.

LÓPEZ, J. 1997. Geomorphological and geological setting of the Río de la Plata. In: Well PG \& GR Daborn (Eds). The Río de la Plata, An environmental overview: 1-16.

López, L., A. Perdomo \& M. Gómez. 1999. Diagnóstico ambiental y socioeconómico de la zona costera uruguaya del Río de la Plata: Recopilación de informes técnicos (Tomo II, Sección III): 208 pp.

LoRENZO, M.I. 1999a. Estimación del crecimiento de la merluza (Merluccius hubbsi) en la zona común de pesca Argentino-Uruguaya. In: Rey, M. \& G. Arena (Eds.) Merluza. Estudios realizados dentro de la Zona Común de Pesca Argentino-Uruguaya en el marco del Plan de Investigación Pesquera URU/ 92/003. ISBN: 9974-563-02-X: 37-52.

LoRENZo, M.I. 1999b. Estimación de las mortalidades de Merluccius hubbsi en la zona común de pesca Argentino-Uruguaya. In: Rey, M. \& G. Arena (Eds.) Merluza. Estudios realizados dentro de la Zona Común de Pesca Argentino-Uruguaya en el marco del Plan de Investigación Pesquera URU/92/ 003. ISBN: 9974-563-02-X: 53-69.

Lubchenco, J., G.W. Allison, S.A. Navarrete, B.A. Menge, J.C. Castilla, O. Defeo, C. Folke, O. Kussakin, T. Norton \& A.M. Wood. 1995. 6.1.9. Coastal systems. In: United Nations Environment Programme. Global Biodiversity Assessment. Section 6: Biodiversity and ecosystem functioning: ecosystem analyses. Cambridge University Press, Cambridge, U.K.: 370-381.

LucchI, C. 1985. Ophiuroidea (Echinodermata) del frente marítimo uruguayo hasta $800 \mathrm{~m}$ de profundidad, con claves para su determinación. Contribuciones del Depto. de Oceanografía, Facultad de Humanidades y Ciencias (Uruguay), 2 (6): 115-171.

MACCHI, G.J. 1997. Reproducción de la corvina rubia (Micropogonias furnieri) del sector ríoplatense. Su relación con los gradientes horizontales de salinidad. Revista Investigaciones Desarrollo Pesquero (Argentina), 11: 73-94.

Macchi, G.J., M. Acha \& C. Lasta. 1996. Desove y fecundidad de la corvina rubia Micropogonias furnieri Desmarest, 1823 del estuario del Río de la Plata, Argentina. Boletín Intituto Español de Oceanografía, 12(2): 99-113.

Macchi, G., \& E.H. Christiansen. 1992. Estudio histológico del ciclo reproductivo en hembras de la corvina rubia (Micropogonias furnieri). Análisis de la estructura madurativa en distintas localidades del área bonaerense. Frente Marítimo (Uruguay), 11: 47-56.

MaCchi, G., \& E.H. Christiansen. 1996. Análisis temporal del proceso de maduración y determinación de la incidencia de atresias en la corvina rubia (Micropogonias furnieri). Frente Marítimo (Uruguay), 16: 93-101.

Mantero, G. 1986. Análisis de los cambios morfológicos en la fase larval de la anchoíta. Publicación de la Comisión Técnica Mixta del Frente Marítimo (Uruguay), 1: 111-120.

Mantero, G. \& A. Errea. 1999. Delimitación de áreas de veda para la protección de juveniles de merluza durante los años 1997-1998. In: Rey, M. \& G. Arena (Eds.) Merluza. Estudios realizados dentro de la Zona Común de Pesca Argentino-Uruguaya en el marco del Plan de Investigación Pesquera URU/ 92/003. ISBN: 9974-563-02-X: 144-152.

Mañé-Garzón, F., E. Dei-Cas, B. Holcman-Spector \& J. LEYMONIE. 1974. Estudio sobre la biología del cangrejo de estuario Chasmagnathus granulata Dana 1851 (I). Osmorregulación frente a cambios de salinidad. Physis, 33: 163-171.

MARín, Y. \& P. PUIG. 1986. La pesquería del tiburón con palangre desde el puerto de La Paloma (19751985). Publicaciones de la Comisión Técnica Mixta del Frente Marítimo 3: 117-123.

Marín, Y., F. Brum, L. BaREA \& J. ChOCCA. 1998. Incidental catch associated with swordfish longline fisheries in the south-west Atlantic Ocean. Marine Freshwater Research, 49: 633-639.

Marín, Y., F. Brum, L. Barea \& J. Chocca. 2000. Captura incidental y su aprovechamiento en la pesquería de pez espada con palangre pelágico en el Atlántico Sudoccidental. Parte 3. In: Arena, G. \& M. Rey (Eds.) Captura de grandes peces pelágicos (pez espada y atunes) en el Atlántico sudoccidental y su interacción con otras poblaciones (Proyecto URU/92/003). 96 pp (ISBN: 9974-563-14-3): 53-69.

Martínez, G. \& S. RetTa. 2001. Caracterización de las áreas de cría de la corvina (Micropogonias furnieri) 
en la costa uruguaya. In: Vizziano D., P. Puig, C. Mesones \& G. Nagy (Eds.) El Río de la Plata. Investigación para la gestión del ambiente, los recursos pesqueros y la pesquería en el frente salino: $141-148$.

Masello, A. \& O. Defeo. 1986. Determinación de la longitud de primera madurez sexual en Mesodesma mactroides (Deshayes 1854). Comunicaciones Sociedad Malacológica del Uruguay, 6(51): 387-395.

Masello, A., R. Cranston, F. Scarabino \& R. Menafra. 1996. Características de las comunidades macrobentónicas y su relación con concentraciones de metales en la costa oeste de Montevideo. In: ECOPLATA'96: Hacia el desarrollo sostenible de la zona costera del Río de la Plata (Montevideo, 25-27 de noviembre de 1996). Resúmenes: 23.

Masello, A. \& R. Menafra. 1996. Macrobenthic community of the uruguayan coast zone and adjacent areas. In: EcoPlata Team (Eds.) The Río de la Plata. An environmental overview. Dalhousie University, Halifax, Nova Scotia: 113162.

Masello, A., F. Scarabino \& M. Gamarra. 2001. Estudio de contenidos estomacales y hábitos alimenticios de Micropogonias furnieri. In: Vizziano D., P. Puig, C. Mesones \& G. Nagy (Eds.) El Río de la Plata. Investigación para la gestión del ambiente, los recursos pesqueros y la pesquería en el frente salino: 149-164.

Maytia, S. \& V. Scarabino. 1979. Las comunidades del litoral rocoso del Uruguay: zonación, distribución local y consideraciones biogeográficas. Memorias del Seminario sobre Ecología Bentónica y Sedimentación de la Plataforma Continental del Atlántico Sur. UNESCO 149-160.

Mclachlan, A., E. Jaramillo, O. Defeo, J. Dugan, A. De Ruyck, \& P. Coetzee. 1995. Adaptations of bivalves to different beach types. Journal of Experimental Marine Biology and Ecology, 187: 147-160.

Mclachlan, A., J. Dugan, O. Defeo, A. Ansell, D. Hubbard, E. Jaramillo \& P. Penchaszadeh. 1996. Beach clam fisheries. Oceanography and Marine Biology, An Annual Review, 34: 163-232.

MÉNDEZ, H. 1982. Florura de Chlorophytas bentónicas de "La Paloma", Departamento de Rocha (ROU). Bachellor Thesis, Facultad de Humanidades y Ciencias. Universidad de la República.

Méndez, S., M. Gómez \& G. Ferrari. 1997. Planktonic syudies of the Río de la Plata and its oceanic front: Well P.G. \& G.R. Daborn (Eds.) The Río de la Plata, An environmental overview: 85-112.

Meneses, P.D. 1999. Distribución espacio temporal y abundancia de los elasmobranquios en el Río de la Plata exterior y zona costera atlántica uruguaya. In: Arena, G. \& M. Rey (Eds.) Estudios realizados sobre los elasmobranquios dentro del Río de la Plata y la Zona Común de Pesca Argentino-Uruguaya en el marco del "Plan de in- vestigación Pesquera" (INAPE-PNUD URU/ 92/003). Montevideo: 38-73.

Menni, R.C. 1983. Los peces en el medio marino. Ed. Sigma, Buenos Aires. 169 pp.

Menni R.C. \& A.E. Gosztonyi. 1982. Benthic and semidemersal fish associations in the Argentine Sea. Studies on Neotropical Fauna and Environment, 17: $1-29$.

Menni, R.C. \& H.L. LóPez. 1984. Distributional patterns of argentine marine fishes. Physis, 42(103): $71-85$.

Menni, R.C. \& F.W. Stehmann. 2000. Distribution, environment and biology of batoid fishes off $\mathrm{Ar}$ gentina, Uruguay and Brazil. A review. Revista del Museo Argentino de Ciencias Naturales, 2(1): 69-109.

Menni, R.C., R.A. Ringuelet \& R.H. Aramburu. 1984. Peces marinos de la Argentina y Uruguay. Ed. Hemisferio Sur, Buenos Aires. 359 pp.

Mesones, C. 1991. Ecología del fitoplancton de superficie en la plataforma continental uruguaya. Bachellor Thesis. Facultad de Ciencias, Universidad de la República, Uruguay: 280p.

Mianzán, M. \& R. Guerrero. 2000. Environmental patterns and biomass distribution of gelatinous macrozooplankton. Scientia Marina, 64: 215-224.

Mianzan, H., N. Mari, B. Prenski \& F. Sánchez. 1996. Fish predation on neritic ctenophores from the Argentine continental shelf: a neglected food resource? Fisheries Research 27: 69-79.

MianZán, H., C. Lasta, M. Acha, R. Guerrero, G. Macch \& C. BRemec. 2000. The Río de la Plata estuary, Argentina-Uruguay: 185-204. In: Seeliger, U. \& B. Kjerfve (Eds.) Coastal Marine ecosystems of Latin America.

Milstein, A. \& M. JuAnicó. 1985. Zooplankton dynamics in Maldonado Bay (Uruguay). Hydrobiologia, 126: $155-164$.

Milstein, A., M. Juanicó \& J. Olazarri. 1976. Algunas asociaciones bentónicas frente a las costas de Rocha, Uruguay. Resultados de la campaña del R/V "Hero", viaje 72-3A. Comunicaciones de la Sociedad Malacológica del Uruguay, 4 (30): 143-164.

Montero, R. 1975. Nota sobre aspectos cuantitativos del zooplancton en las zonas de influencia del Río de la Plata. Revista de Biología del Uruguay (Uruguay), 3(1): 37-42.

Montú, M. 1997. Zooplankton: Seeliger, U., C. Odebrecht \& J.P. Castello (Eds.). Subtropical Convergence Environments. The Coast and the Sea in the Southwestern Atlantic, 110-113.

Müller-Melchers F.E. 1959. Plankton diatoms of the Southern Atlantic Argentina and Uruguay coasts. Comunicaciones Botánicas Museo Historia Natural (Uruguay), 3: 1-53.

Muñiz, P. \& Venturini N. 2001. Spatial distribution of the macrozoobenthos in the Solís Grande stream estuary (Canelones-Maldonado, Uruguay). Brazilian Journal of Biology, 61, 409-420. 
Nagy, G., C. Martínez, R.M. Caffera, G. Pedrosa, E.A. Forbes, A.C. Perdomo, J .López. 1997. The hydrological and climatic setting of the Río de la Plata: 17-68. In: Well, P.G. \& G.R. Daborn (Eds.) The Río de la Plata, An environmental overview.

Negri, R.M., H.R. Benavides \& J.I. Carreto. 1988. Algunas características del florecimiento del fitoplancton en el frente del Río de la Plata II: las asociaciones fitoplanctónicas. Publicaciones Comisión Técnica Mixta Frente Marítimo (Uruguay), 4: 151-161.

Neirotti, E. 1981. Estudio comparativo del supralitoral y mesolitoral rocoso en diferentes localidades del estuario del Río de la Plata. Comunicaciones de la Sociedad Malacológica del Uruguay, 5 (40): 347-370.

Niencheski, L. \& Fillmann G. 1997. Chemical characteristics: 96-98. In: Seeliger, U., C. O. Debrecht \& J.P. Castello (Eds.). Subtropical Convergence Environments. The Coast and the Sea in the Southwestern Atlantic.

Niggemeyer, F. \& A. Masello. 1992. La pesquería del mejillón (Mytilus edulis platensis): análisis de los desembarques en el puerto de Punta del Este (Maldonado, Uruguay). Publicaciones de la Comisión Técnica Mixta del Frente Marítimo (Uruguay), 12A:83-88

Nión, H. 1985. Análisis de la investigacion biológicopesquera en el Uruguay. In: Evaluación y Perspectivas del Complejo Pesquero Uruguayo. CIEDUR Serie Investigaciones $\mathrm{N}^{\mathrm{o}} 22.162 \mathrm{pp}$.

Nión, H. 1998. Peces del Río de la Plata y algunos aspectos de su ecología. Capítulo 6. pp: 169-190. In: Wells, P.G. \& G.R. Daborn (Eds.) El Río de la Plata. Una revisión Ambiental. Dalhousie University, Halifax, Nova Scotia, Canada. 256 pp.

Nión, H. 1999. La pesquería de tiburones en el Uruguay, con especial referencia al cazón (Galeorhinus galeus Linnaeus, 1758). In: Shotton R. (Ed.) Case studies of the management of elasmobranch fisheries. FAO Fisheries Technnical Paper $\mathrm{N}^{\circ} 378$, part 1: 218-267.

Nión, H. \& C. Ríos. 1991. Los recursos pelágicos del Uruguay. Atlântica (RS, Brasil) 13: 201-215.

Nión, H., C. Ríos, R. Leta \& J.C. Elgue. 1986. Descripción de un área de cría multiespecífica en el frente oceánico del Uruguay. $2^{\mathrm{a}}$ parte. Publicaciones Comisión Técnica Mixta Frente Marítimo (Uruguay), 1(2): 369-408.

Norbis, W. 1992. Crecimiento y mortalidad del papamoscas (Cheilodactylus bergi) en la Zona Común de Pesca Argentino-Uruguaya. Frente Marítimo (Uruguay), 12: 57-70.

Norbis, W. 1993. Estructura y Persistencia de la Comunidad de Peces Demersales en el Frente Oceánico del Río de la Plata. PhD Thesis Dissertation. University of Barcelona-Universidad Politécnica de Catalunya, Barcelona - España. 452 pp.

NorBIs, W. 1998. Estructura de la población y carácter de la migración del papamoscas (Cheilodactylus bergi) en la Zona Común de Pesca Argentino-Uruguaya. Frente Marítimo (Uruguay), 17: 17 - 38.

Norbis, W. 1999a. Características del desove del papamoscas (Cheilodactylus bergi) (Pisces, Cheilodactylidae) en relación a las condiciones ambientales. Boletín de la Sociedad de Zoología del Uruguay (2º́poca) (Uruguay) 10: 83-100.

Norbis, W. 1999b. Estudios de las asociaciones de lances y especies en base a datos colectados en las campañas de evaluación realizadas dentro de la Zona Común de Pesca Argentino-Uruguaya. Otoño y primavera de 1994: 26-36. In: Rey, M. \& G. Arena (Eds.) Merluza. Estudios realizados dentro de la Zona Común de Pesca ArgentinoUruguaya en el marco del Plan de Investigación Pesquera (URU/92/003) ISBN: 9974-563-02-X.

Norbis, W. \& O. GaLli. 1999. Sinopsis sobre la merluza (Merluccius hubbsi): 11-15. In: Rey, M. \& G. Arena (Eds.) Merluza. Estudios realizados dentro de la Zona Común de Pesca Argentino - Uruguaya en el marco del Plan de Investigación Pesquera (Proyecto URU/92/003). ISBN: 9974563-02-X.

Norbis, W. \& D. Severov. 1999. Resultados de los avances de investigación aplicados a las campañas de delimitación del área de veda de la merluza (Merluccius hubbsi) en la zona común de pesca Argentino-Uruguaya: 164-169. In: Rey, M. \& G. Arena (Eds.) Merluza. Estudios realizados dentro de la Zona Común de Pesca Argentino - Uruguaya en el marco del Plan de Investigación Pesquera URU/92/003 ISBN: 9974-563-02-X.

Norbis, W., M.I. LORENZO \& G. TORRES. 1999. Intra-annual growth variations of the young-of-the-year hake (Merluccius hubbsi) of the uruguayan continenntal shelf, based on otolith analysis. Fisheries Research, 44: 129 - 137.

Norbis, W., L. Paesch, J. Verocai \& G. Villamarín. 1992. Cambios en la estructura de la población de corvina (Micropogonias furnieri) capturada en la pesquería artesanal de Pajas Blancas (Montevideo, Uruguay). Frente Marítimo (Uruguay), 11: 37-46.

Odebrecht, C.O. \& C.A.E. García. 1997. Phytoplankton: 105-107. In: Seeliger, U., C. Odebrecht \& J.P. Castello (Eds.). Subtropical Convergence Environments. The Coast and the Sea in the Southwestern Atlantic.

Odebrecht, C.O. \& J.P. Castello. 2000. The convergence ecosystem in the Southwest Atlantic: 147-162. In: Seeliger, U. \& B. Kjerfve (Eds.). Coastal marine ecosystems of Latin America.

Odebrecht C.O. \& L. Duurfeldt. 1996. The role of nearshore mixing on the phytoplankton size structure off Cape Santa Marta Grande, Southern Brazil (Spring 1989). Archive of Fisheries and Marine Research, 43(3): 13-26.

OLIVIER, S.R. \& V. SCARABINO. 1972. Distribución ecológica de algunos moluscos recogidos por la expedición 
del "Walther Herwig" (R.F.A.) al Atlántico Sudoccidental (1966). Revista Brasileira de Biologia (Brazil), 32 (20): 235-247.

Olivier, S., R. Bastida \& M. Torti. 1968. Sobre el ecosistema de las aguas litorales de Mar del Plata. Publicación del Servicio de Hidrografía Naval, Buenos Aires. 45 pp.

Olivieri, C. \& H.E. Christiansen. 1987. Consideraciones preliminares sobre la frecuencia reproductiva de la merluza común (Merluccius hubbsi). Publicaciones Comisión Técnica Mixta Frente Marítimo (Uruguay), 3: 67 - 72.

Olson, D.B., G.P. Podestá, R.H. Evans \& O.B. Brown. 1988. Temporal variations in the separation of Brasil and Malvinas currents. Deep Sea Research, 35: 71-90.

Otero, H. 1986. Determinación del ciclo migratorio de la merluza común (Merluccius hubbsi) mediante el análisis de índices de densidad poblacional y concentración del esfuerzo de pesca. Publicaciones Comisión Técnica Mixta Frente Marítimo(Uruguay), 1(1): 75-92.

Otero, H., M.S. Giangiobbe \& M.A. Renzi. 1986. Aspectos de la estructura de población de la merluza común (Merluccius hubbsi). II. Distribución de tallas y edades, estadíos sexuales. Variaciones estacionales. Publicaciones Comisión Técnica Mixta Frente Marítimo (Uruguay), 1(1): $147-179$.

Otero, H., S.I. Bezzi, M.A. Renzi \& G.A. Verazay. 1982. Atlas de los recursos pesqueros demersales del Mar Argentino.INIDEP, Argentina. Contribución $\mathrm{N}^{\circ}$ 423: 248 pp.

Paesch, L. 1999. Biomasa y rendimientos de los elasmobranquios. Estructura de población de Squalus acanthias, Squalus mitsukurii, Dipturus chilensis y Sympterygia bonapartii: 13-37. In: Arena, G. \& M. Rey (Eds.) Estudios realizados sobre los elasmobranquios dentro del Río de la Plata y la Zona Común de Pesca Argentino-Uruguaya en el marco del "Plan de Investigación Pesquera" (INAPE-PNUD URU/92/003).

PAesch, L. 2000. Hábitos alimentarios de algunas especies de elasmobranquios en el frente oceánico del Río de la Plata. Frente Marítimo (Uruguay), 18: 71-90.

Paffenhofer, G.A. 2001. Future Marine Zooplankton Research-a perspective (Marine Zooplankton Colloquium 2). Marine Ecology Progress Series, 222: 297-308.

Pintos, W., D. Conde, R. de León, M. Cardezo \& A. JorCín. 1991. Some limnological characteristics of Laguna de Rocha (Uruguay). Revista Brasileira de Biologia (Brazil), 51: 79-84.

Ponce de León, A. 1999. Mamíferos: 45-46. In: López, L., A. Perdomo \& M. Gómez. (Eds.) Diagnóstico ambiental y socioeconómico de la zona costera uruguaya del Río de la Plata: Recopilación de informes técnicos (Tomo II, Sección III).

Ponce de León, A., O.D. Pin \& M. Arim. 2000.
Identificación de presas en contenido estomacal y fecas de ejemplares de lobo fino Arctocephalus australis del rebaño de Isla de Lobos, Uruguay: 37-51. In: Ponce de León, A. (Ed.) Sinopsis de la biología y ecología de las poblaciones de lobos finos y leones marinos de Uruguay, pautas para su manejo y administración INAPE-PNUD.

Praderi, R., M.C. Pinedo \& E.A. Crespo. 1989. Conservation and management of Pontoporia blainvillei in Uruguay, Brazil and Argentina: 52-56. In: Perrin, W.F., R.L. Brownell, Z. Kaiya \& L. Jiankang. (Eds.). Biology and Conservation of the River Dolphins. Occassional Papers IUCN SSC3.

Pravia, M., C. García, L. Ares \& N. Berois. 1995. Estimación de la fecundidad y determinación del tipo de desova de la corvina blanca, Micropogonias furnieri (Teleostei: Sciaenidae). Revista Brasilera de Biologia (Brazil), 55: 13-25.

Prensky, B. \& F. SÁnchez. 1988. Estudio preliminar sobre asociaciones ícticas en la Zona Común de Pesca Argentino-Uruguaya. Publicaciones Comisión Técnica Mixta Frente Marítimo(Uruguay), 4: $75-88$.

Puig, P. 1986. Análisis de contenidos estomacales de corvina blanca (Micropogon opercularis) (Sciaenidae, Perciformes). Verano 1984. Publicación de la Comisión Técnica Mixta del Frente Marítimo (Uruguay), 1: 333-340.

Ramírez, F.C. 1970. Copépodos planctónicos del sector bonaerense del Atlántico Sudoccidental. Proyecto Desarrollo Pesquero, Mar del Plata, Serie Informes Técnicos, $\mathrm{N}^{\circ} 10 / \mathrm{XV}$ : 1-116.

Ramírez, F.C. 1973. Eufausidos de la campaña oceanográfica "Walther Herwing" 1966. Physis, 32(84): 105-114.

Ramírez, F.C. \& M.O. Zamponi. 1980. Medusas de la plataforma Bonaerense y aguas adyacentes. Physis, 39(96): 33-48.

Resgalla, C., C. de la Rocha \& M. Montú. 2001. The influence of Ekman transport on zooplankton biomass variability off southern Brazil. Journal Plankton Research, 23(6): 641-650.

Rey, M. \& P. GRunwaldT. 1986. Evaluación de la merluza (Merluccius hubbsi) en la Zona Común de Pesca Argentino-Uruguaya. Publicaciones Comisión Técnica Mixta Frente Marítimo (Uruguay), 1(1): $121-134$

Rey, M., S. Bezzi, G. Verazay \& J. Oribe. 1996. Areas de veda para la protección de los juveniles de merluza (Merluccius hubbsi) en la Zona Común de Pesca, hasta diciembre de 1993. Frente Marítimo (Uruguay), 16: 7-28.

RIESTRA, G. 1999. La comunidad macrobentónica asociada al Mejillón Mytilus edulis platensis en costas del Departamento de Maldonado: variación espacio-temporal e incidencia del impacto pesquero. MSc.Thesis, Pedeciba, Universidad de la República, Uruguay. 67 pp.

RIESTRA, G. 2000. Análisis de la fauna acompañante asocia- 
da a la pesquería de Zygochlamys pata-gonica en aguas uruguayas: 153-157. In: Rey, M. (Ed.). Recursos pesqueros no tradicionales: moluscos bentónicos marinos. Proyecto URU/92/003, INAPE-PNUD.

Riestra, G. \& O. Defeo. 1994. Aspectos de la dinámica poblacional y estructura de la comunidad del mejillón Mytilus edulis platensis en la costa atlántica uruguaya. Publicaciones de la Comisión Técnica Mixta del Frente Marítimo (Uruguay), 7(66-67):345-356.

Riestra, G. \& L. BAREA. 2000. La pesca exploratoria de la vieira Zygochlamys patagonica en aguas uruguayas: 145-152. In: Rey, M. (Ed.) Recursos pesqueros no tradicionales: moluscos ben-tónicos marinos. Proyecto URU/92/003, INAPEPNUD.

Riestra, G., G. Fabiano, R. Foti \& O. Santana. 1997. Mortandad de organismos bentónicos en la costa Atlántica del Uruguay. Comunicaciones de la Sociedad Malacológica del Uruguay (Uruguay), 72/73: 73-79.

Riestra, G., J.L. GimÉnez \& V. Scarabino. 1992. Análisis de la comunidad macrobentónica infralitoral de fondo rocoso en Isla Gorriti e Isla de Lobos (Maldonado, Uruguay). Frente Marítimo (Uruguay), 11: 123-127.

Riestra, G., O. Defeoo \& A. Brazeiro. 1996. Dinámica de la zonación de gasterópodos en una playa disipativa micromareal. Comunicaciones de la Sociedad Malacológica del Uruguay, 8(70-71): 1-6.

Riestra, G., G. Fabiano \& O. Santana. 2000. El caracol negro Adelomelon brasiliana como recurso no tradicional de importancia para el país: análisis socieconómico de la pesquería y medidas precautorias de manejo: 82-92. In: Rey, M. (Ed.) Recursos pesqueros no tradicionales: moluscos bentónicos marinos. Proyecto URU/92/003, INAPE-PNUD.

Ringuelet, R. \& R.H. Aramburu. 1960. Peces marinos de la República Argentina. Clave de familias y géneros y catálogo crítico abreviado. Agro (Argentina), 2(5): 1-141.

Ríos, C., H. Leta, O. Mora, \& J.C. Rodríguez. 1986. La pesca de atunes y especies afines por parte de la flota palangrera de altura uruguaya. Publicación de la Comisión Técnica Mixta del Frente Marítimo (Uruguay), 1(2): 483-544.

SAIZ, E. \& T. Kiorbo. 1995. Predatory and suspension feeding of the copepod Acartia tonsa in turbulent environments. Marine Ecology Progress Series, 122:147-158

SANCHEZ R. 1991. Reseña de las investigaciones sobre ictioplancton marino en Argentina y Uruguay. Atlântica (RS, Brazil), 13: 215-231.

SANTOS, B. \& F.C. RAMírez. 1991. Variación estacional en las asociaciones de copépodos en una transecta de la plataforma argentina. Boletim Instituto Oceanografico (S.P., Brazil), 39: 71-86.
SCARABINO, V. 1977 (“1976-1977”). Moluscos del Golfo de San Matías (Provincia de Río Negro, República Argentina). Inventario y claves para su identificación. Comunicaciones de la Sociedad Malacológica del Uruguay, 4 (31/32): 177-263, 11 láms.

Scarabino, V. 1983. Contenido estomacal de Bathybiaster herwigi (Bernasconi, 1972), asteroideo batial del Atlántico Sudoccidental. Resúmenes y Comunicaciones de las Terceras Jornadas de Ciencias Naturales: 13. Montevideo.

Scarabino, V., S. Maytía, \& J.C. Faedo. 1974. Zonación biocenológica de las playas arenosas del Depto. de Rocha (Uruguay), con especial referencia a la presencia de Ocypode quadrata (Fabricius, 1787) (Decapoda, Brachyura). Boletín de la Comisión Nacional de Oceanología (Uruguay), 1 (1): 42-52, 2 láms., 1 mapa.

SCARABINO, F. \& M. Verde. 1995. ("1994”). Limnoperna fortunei (Dunker, 1857) (Bivalvia; Mytilidae) en la costa uruguaya del Río de la Plata. Comunicaciones de la Sociedad Malacológica del Uruguay, 7 (66/67): 374-375.

Scarabino, V., S. MaYtía \& M. Cachés. 1975. Carta bionómica litoral del Departamento de Montevideo. I. Niveles superiores del sistema litoral. Comunicaciones de la Sociedad Malacológica del Uruguay, 4: 117-129.

Seeliger, U., C. Odebrecht \& J.P. Castello. 1997. Subtropical Convergence Environments. The Coast and the Sea in the Southwestern Atlantic. Springer Berlin. 308 pp.

Seijo, J.C. \& O. Defeo. 1994. Dynamics of resource and fishermen behaviour in coastal invertebrate fisheries: 209-222. In: Antona E,. J. Catanzano \& J.G. Sutinen (Eds). Proceedings of the VI Conference of the International Institute of Fisheries Economics and Trade.

Seijo, J.C., O. Defeo \& A. de Alava. 1994. A multiple criterion optimization approach for the management of a multispecies fishery with ecological and technological interdependencies: 161-169. In: Antona, E., J. Catanzano \& J.G. Sutinen (Eds.). Proceedings of the VI Conference of the International Institute of Fisheries Economics and Trade.

Severov, D. 1999. Variabilidad de la área de veda en 1991-1998 y su relación con la dinámica del frente sur-subtropical: 170-183. In: Rey, M. \& G. Arena (Eds.). Merluza. Estudios realizados dentro de la Zona Común de Pesca ArgentinoUruguaya en el marco del Plan de Investigación Pesquera URU/92/003. ISBN: 9974-563-02-X.

Smonazzi, M.A. \& H.O. Otero. 1986. Aspectos de la estructura de la población de la merluza común (Merluccius hubbsi). I. Largo y edad de primera madurez, relación largo-peso. Publicaciones Comisión Técnica Mixta Frente Marítimo (Uruguay), 1(1): 135 - 146.

Sinclair, M. 1988. Marine Populations: an essay on 
population regulation and speciation. University of Washington Press, Seattle, WA. 252 pp.

SinClaIR, M. \& T.D. ILES. 1989. Population regulation and speciation in the oceans. Journal Conseil international pour l'Exploration de la Mer, 45: 165-175.

Sinque, C. \& H. Muelbert. 1997. Ichtyoplankton:120123. In: Seeliger, U., C. Odebrecht \& J.P. Castello (Eds.). Subtropical Convergence Environments. The Coast and the Sea in the Southwestern Atlantic.

SMETACEK, V. 1981. The annual cycle of protozooplankton in Kiel Bight. Marine Biology, 63: 1-11.

Souto, S. 1974. Tintínidos del Río de la Plata y su zona de influencia (Protozoa, Ciliata). Physis, 33(87): 201-205.

SpinetTi, M. 2000. Cuantificación de las capturas de lenguado Paralichtys spp. en los desembarques del puerto de Montevideo en 1996: 75-83. In: M. Rey (Ed.). Recursos pesqueros no tradicionales: moluscos, crustáceos y peces bentónicos marinos. Proyecto URU/92/003. INAPE-PNUD.

SzTEREN, D. 1999. Impacto económico del león marino sudamericano (Otaria flavescens) sobre la pesca artesanal en Uruguay. MSc Thesis Universidad de Córdoba, Argentina. 59 pp.

Szteren, D. \& E. PÁez. 2002. Predation of southern sea lions (Otaria flavescens) in artisanal fishing operations in Uruguay. Marine and Freshwater Research (in press).

UbaL, W. 1986. Análisis cualitativo y cuantitativo de la alimentación de la merluza (Merluccius hubbsi) en la Zona Común de Pesca Argentino - Uruguaya. Publicaciones Comisión Técnica Mixta Frente Marítimo (Uruguay) 1(2): 281-298.

Ubal, W., W. Norbis, B. Bosch \& D. Pagano. 1987a. Principales factores determinantes de la abundancia de la merluza (Merluccius hubbsi) en otoño en la Zona Común de Pesca Argentino-Uruguaya. Publicaciones Comisión Técnica Mixta Frente Marítimo (Uruguay), 3: 7-14.

Ubal, W., W. Norbis, B. Bosch \& D. Pagano. 1987c. Estudio del stock desovante de la merluza (Merluccius hubbsi) en la Zona Común de Pesca ArgentinoUruguaya. Publicaciones Comisión Técnica Mixta Frente Marítimo (Uruguay), 3: 59-66.

Ubal, W., W. Norbis, B. Bosch, M. Parietti \& D. PagaNo. 1987b. Migración de la merluza (Merluccius hubbsi) por seguimientos de rangos de longitud en la Zona Común de Pesca Argentino-Uruguaya. Publicaciones Comisión Técnica Mixta Frente Marítimo (Uruguay), 3: 15-24.

UNESCO. 1980. Conservación y mejora de playas. Proyecto UNDP/URU/73/ 007, Informe Técnico, $593 \mathrm{pp}$.

VAZ FERREIRA R. 1965. Ecología terrestre y marina de los Pinnipedios del Atlántico Sudoccidental. Anais da Academia Brasileira de Ciencias (Brazil), 37:179-191.

Vaz Ferreira R. 1972. Ocupación de espacios y reproducción de Otaria flavescens (Shaw) "lobo de un pelo", en áreas periféricas o apartadas del criadero. Boletín de la Sociedad Zoológica del Uruguay (Uruguay), 2: 8-12.

VAz FERREIRA R. 1975a. Behavior of the southern sea lion Otaria flavescens (Shaw) in the Uruguayan islands. Rapport Processeaux Verbaux Reunion Conseil International Exploration Mer, 169: 219227.

Vaz FerReira R. 1975b. Factors affecting numbers of sea lions and fur seals on the Uruguayan islands. Rapport Processeaux Verbeaux Reunion Conseil International Exploration Mer, 169: 257-262.

VAZ FERREIRA R. 1987. Ecology, behavior and survival of the South American fur seal in Uruguay: 165168. In: Croxall J.P. \& R.L. Gentry (Eds.). Status, Biology, and Ecology of Fur Seals. Proceedings of an International Symposium and Workshop. Cambridge, England. NOAA Technical Report NMFS 51.

Venturini, N., M. Rodríguez \& P. Muniz. 1999. Comunidades bentónicas submareales de la Bahía de Montevideo y su relación con los aportes de materia orgánica en la región. Boletín de la Sociedad Zoológica del Uruguay (Actas de las V Jornadas de Zoología del Uruguay), 11 (Segunda Epoca): 48.

Verity, P.G. \& V. Smetacek. 1996. Organism life-cycles, predation, and the structure of marine pelagic ecosystems. Marine Ecology Progress Series, 130: 277-293.

Viana, F., A. Acuña, N. Berois \& E. Danulat. 2000. Testes morphology and reproductive aspects of male Brazilian codling (Urophycis brasiliensis Kaup 1858). Journal of Applied Ichthyology, 16: 134-135.

Vizziano, D. 2001. Determinación del ciclo reproductivo de la corvina Micropogonias funieri (Pisces: Scienidae) y los factores que inciden en su estacionalidad en la zona frontal del Río de la Plata: 105-114. In: Vizziano D., P. Puig, C. Mesones \& G. Nagy (Eds.). El Río de la Plata. Investigación para la gestión del ambiente, los recursos pesqueros y la pesquería en el frente salino.

Vizziano, D. \& N. Berois. 1990. Ciclo histológico del ovario de Macrodon ancylodon (Bloch \& Schneider 1801) (Teleostei: Sciaenidae). Biología Pesquera (Chile), 19: 39-47.

Vizziano, D., G. Saona, J. Franco \& G. Nagy. 2001. Caracterización ambiental del área de desove de la corvina blanca Micropogonias furnieri en la zona frontal del Río de la Plata: 108-125. In: Vizziano, D., P. Puig, C. Mesones \& G. Nagy (Eds.). El Río de la Plata. Investigación para la gestión del ambiente, los recursos pesqueros y la pesquería en el frente salino.

WeIss, G. \& JAF SouZA. 1977. Estudo comparativo preliminar de pôs-larvas e juvenis das três espécies de engraulidos da costa sul do Brasil, Uruguai e 
Gayana 67(2), 2003

Argentina. Atlântica (RS, Brazil), 1(2): 1-20.

Weiss, G., JAF SouZa \& A. Santos. 1976. Contribuçao ao conhecimento do ictioplâncton marino na costa sul do Brasil. Atlântica (RS, Brazil), 1(1/2): 199.

Woodd-Walker, R.S., P. Ward \& A. Clarke. 2002. Large-scale patterns in diversity and community structure of surface water copepods from the Atlantic Ocean. Marine Ecology Progress Series, 236: 189-203.
Yannicelli, B., R. Palacios \& L. Giménez. 2001. Activity rhythms of two cirolanid isopods from an exposed microtidal sandy beach in Uruguay. Marine Biology, 138: 187-197.

Yannicelli, B., R. Palacios \& L. Giménez. 2002. Swimming ability and burrowing time of two cirolanid ispods from different levels of exposed sandy beaches. Journal of Experimental Marine Biology and Ecology, 273: 73-88.

Fecha de recepción: 05/05/03

Fecha de aceptación: 151/09/03 